NBER WORKING PAPER SERIES

TECHNOLOGY AND TRADE

Gene M. Grossman

Elhanan Helpman

Working Paper No. 4926

\author{
NATIONAL BUREAU OF ECONOMIC RESEARCH \\ 1050 Massachusetts Avenue \\ Cambridge, MA 02138 \\ November 1994
}

A version of this paper will appear as a chapter in The Handbook of International Economics, vol. 3, edited by G. Grossman and K. Rogoff. We thank Jim Anderson, Pranab Bardhan, Jon Eaton, and Jim Markusen for their comments and suggestions, and the National Science Foundation and the U.S.-Israel Binational Science Foundation for financial support. Grossman also thanks the John S. Guggenheim Memorial Foundation, the Sumitomo Bank Fund, the Daiwa Bank Fund, and the Center of International Studies at Princeton University. This paper is part of NBER's research program in Intemational Trade and Investment. Any opinions expressed are those of the authors and not those of the National Bureau of Economic Research.

(C) 1994 by Gene M. Grossman and Elhanan Helpman. All rights reserved. Short sections of text, not to exceed two paragraphs, may be quoted without explicit permission provided that full credit, including $(\mathcal{O}$ notice, is given to the source. 
NBER Working Paper \#4926

November 1994

\title{
TECHNOLOGY AND TRADE
}

\begin{abstract}
We survey research on the relationship between technology and trade. We begin with the old literature, which treated the state of technology as exogenous and asked how changes in technology affect the trade pattern and welfare. Recent research has attempted to endogenize technological progress which results either from learning-by-doing or from investments in research and development. This allows one to examine not only how technology affects trade, but also how trade affects the evolution of technology. We emphasize the parallels between the models with learning-by-doing and those with explicit R\&D and highlight the role that the geographic extent of knowledge spillovers plays in mediating the relationship between trade and technological progress.
\end{abstract}

Gene M. Grossman Woodrow Wilson School

Princeton University Princeton, NI 08544 and NBER
Elhanan Helpman

Eitan Berglas School of Economics

Tel Aviv University

Tel Aviv, ISRAEL 69978 and NBER 
Ever since David Ricardo published his Principals of Political Economy, crosscountry differences in technology have featured prominently in economists' explanations of the international pattern of specialization and trade. ${ }^{I}$ Yet, until quite recently, the formal trade-theory literature has focused almost exclusively on the effects of technological disparities without delving much into their causes.

This focus-which undoubtedly has produced many useful insights-is nonetheless somewhat surprising. After all, informal commentators see the integration of the world econony as having an important influence on the pace and direction of technological cliange. Indeed, allusions to "globalization" pervade popular discussious of recent techuological developments, where trade is seen variously as a "higliway' of learning" and a "handmaiden of growth". Global integration presumably affects both the private incentives for and the social benefits from investments in technology. On the positive side, integration expands the size of the market and so the poteutial profit opportunities available to a firm that succeeds in inventing a new product or process. Also, because knowledge is the quintessential public good, a country that integrates itself into the world economy often can benefit from learning that takes place outside its borders. On the negative side, firms sometimes cite international competition as one of the major risks associated with investments in high technology and as an element in the case for greater government involvement in the development of new technologies.

The prolonged absence of a formal literature on the determinants of national productivity levels and on the relationship between trade and technological progress

\footnotetext{
${ }^{1}$ In his famous wine-and-cloth example, Ricardo gave no explicit reasons for the difference in
} comparative costs between Portugal and England. Many believe that Ricardo thought exclusively in terms of differences in soil, climate and national character, rather than in terms of cross-country differences in knowledge. But Ricardo clearly was aware that differences in production capabilities could accourt for comparative advantage. He even discussed a case where the discovery of a new production process for wine making in England might flip the international pattern of specialization and trade (Ricardo, [1951-55, pp.137-138]). Other classical writers, including John Stuart Mill, Torrens, Malthus, and Cairns, regularly pointed to technological disparity in addition to other factors as a potential source of coinparative advantage. Bloomfield (1978) examines the views of the nineteenth-century British authors on the role of technology in trade. 
cannot be ascribed to lack of interest. Rather, trade theorists lacked the tools needed to deal with these issues. Since most of the costs of developing a new technology occur before production begins and do not vary with the intended scale of output, innovation normally gives rise to dynamic scale economies. And since firms typically cover the costs of their up-front investments by exploiting market power generated by their inventions, innovation gives rise to imperfect competition. Not until scale economies and imperfect competition had been incorporated into static trade theory (a development that is reviewed in Chapter 1 of this volume) could dynamic theories of the relationship between trade and technology evolve.

The modelling efforts that we survey in this chapter have been motivated by a number of important concerns. Some of these concerns remain the same as in earlier work on trade and growth (which was reviewed by Ronald Findlay (1984) in the first volume of the Handbook of International Economics]. For example, many authors continue to be interested in the link between the nature of differences in countries' technological capabilities and the pattern of world trade. Recent research has asked, How will an across-the-board technological gap between rich and poor countries be reflected in global trade structure?. And how will the invention of new goods in the industrialized "North" affect the number and type of goods that are produced by the less developed "South." Also, attention still focuses on the age-old question of how technological developments in one country or region affect living standards abroad. Should a country be happy to see technological progress in its trade partners, or should it disparage the consequent "loss of competitiveness"? Is trade typically beneficial to all parties in a world of unequal (and changing) technological capabilities or might some be losers in the long run?

However, many of the questions posed in the recent literature-while long of interest to trade economists and often made the subject of their informal writings-could not be addressed in a formal and rigorous way using the static models of old. At the most general level, there is the question: How does trade affect a country's (and the world's) growth rate? Will every country grow faster if it chooses to be open to international trade? Or does the answer depend on the nature of its natural endowments, 
its initial conditions, or something else? One wonders also whether, over time, trade will tend to shrink the enormous disparities that exist between countries' productivity and income levels, or whether the differences should be expected to persist or even grow. In other words, are there mechanisms unleashed by international integration that serve to close the technological gaps between nations? Or are technological processes better seen as cumulative, so that trade might reinforce the initial gaps?

These positive questions suggest some normative ones, which have also been addressed in the research we describe. What is the relationship between the national growth rate and welfare in an open economy? What policies are likely to promote productivity growth and national welfare? Should a country's trade stance depend on its stage of technological development, with lagging countries perhaps needing some form of protection until the technological gap between themselves and their trade partners has been narrowed or closed? Can temporary policies have long-lasting, beneficial effects? And how do the trade and technology policies in one country impact upon its trade partners?

As always, the answers to such questions depend upon the particular assumptions that are made about the economic environment. The literature has explored a wide variety of assumptions, in models that are not always readily comparable. One clear distinction concerns the driving force behind technological progress. Many recent (and older) writings investigate technical gains that stem from learning-bydoing; that is, the mere repetition of certain productive activities, which may allow firms and industries to find new and better ways of doing things. Another body of research focuses more on research and development; that is, on investments in activities undertaken with the primary or sole objective of discovering new technologies. Besides this fundamental distinction there are other, more subtle ones. Technological improvements may be targeted at intermediate goods or at final goods. Newly discovered products may be better than older varieties or merely different from them. Investments in knowledge may generate widespread benefits or benefits that are fully appropriable by the investor. If spillovers do occur, they may take place across firms in an industry, across industries in a country, or across national borders. And so on. 
One of our goals in this chapter is to provide a unified and synthetic treatment of the various models, so that their common elements can be appreciated and their essential distinguishing features understood. In this way, the different answers they give to the above-mentioned questions can be linked to differences in primitive assumptions. Hopefully, this will pave the way for empirical work aimed at identifying the more realistic of the alternative assumptions.

We have divided the chapter into four sections. The first one reviews the literature that takes technology as exogenous and examines the implications of productivity differences for trade patterns and the effects of technical change on outputs and welfare. This sets the stage for Sections 2 and 3, both of which treat dynamic models in which the evolution of technology is endogenous. In Section 2, technological progress is viewed as an accidental by-product of production activities, while in Section 3 it results from deliberate investment. The various sub-sections explore the implications of alternative assumptions about the form of industrial innovation and the nature of technological spillovers. The last section contains a melange of topics not covered elsewhere, including a discussion of the effects of trade and industrial policies, of trade based on imitation in a setting of imperfectly-protected intellectual property rights, and of direct foreign investment and international licensing as vehicles for technology transfer.

\section{Exogenous Technology}

In what follows we will largely be concerned with how the international trading environment affects the pace and direction of technological change. In our view, the trade pattern should properly be regarded as a dynamic phenomenon, responding continuously to the ebbs and flows of accumulating knowledge. Moreover, foreign market opportunities and international competition have an important influence on the course of technological progress. Yet even if one adopts this perspective on world trade, it is necessary to understand fully how technology differences shape the pattern of global specialization before proceeding to the full dynamic process. This is 
because, in the short run, history dictates a relatively fixed distribution of knowledge, and the resource allocations effected by this momentary distribution weigh heavily in the determination of subsequent technological developments.

We begin this section with a review of the familiar Ricardian model, including extensions that allow for a continuum of goods. We then show how, by adding structure to the model, it can shed light on some commonly observed trade dynamics. After a brief mention of several elaborations that allow for more than one factor of production, we conclude the section with a discussion of the effects of exogenous technological progress on national welfare levels.

\subsection{The Ricardian Model}

The Ricardian model provides the simplest framework in which one can examine how national differences in technological capabilities give rise to specialization and trade. We review this venerable model in order to introduce notation and to recall some results for later use.

In the simplest Ricardian setting, there are two countries, two goods, and a single factor of production. With only one productive factor, the composition of countries' endowments are bound to be identical. This leaves tastes and technology as the only dimensions along which countries may differ. (We ignore government policies and institutional disparities for the time being.) Technologies are characterized by constant returns to scale, and so can be fully described by a single number. In the home country, $a$; units of labor are needed to produce one unit of good $i, i=x, y$. Unit labor coefficients for the foreign country are similar, but are distinguished by an asterisk. Then the model predicts-as is very well known-that comparative ad vantage alone determines the pattern of trade. That is, in a competitive equilibrium with freely transportable goods but imnobile labor, the home country exports good $x$ if and only if $a_{x} / a_{y}<a_{x}^{*} / a_{y}^{*}$. This can be seen in Figure 1, which also shows the different types of equilibria that are possible.

Assume for concreteness that $a_{x} / a_{y}<a_{x}^{*} / a_{y}^{*}$. Then both countries will specialize in the production of good $y$ (and therefore world output of good $x$ is nil) if $p_{x} / p_{y}<a_{x} / a_{y}$, 
where $p_{i}$ denotes the price of good $i$. This is because the cost of producing good $i$ at home is $w a_{i}$, where $w$ is the home wage rate, and production of a good is profitable if and only if its unit cost does not exceed the price. Thus, if $p_{x} / p_{y}<a_{x} / a_{y}$, production of good $x$ is not profitable at home and, a fortiori, not profitable abroad. By similar reasoning both countries will specialize in the production of good $I$ if $p_{x} / p_{y}>a_{x}^{*} / a_{y}^{*}$, in which case the world supply of this goods equals $L / a_{x}+L * / a_{x}^{*}$, where $L$ and $L^{*}$ are the home and foreign labor supplies, respectively. If $a_{x}^{*} / a_{y}^{*}>$ $p_{x} / p_{y}>a_{x} / a_{y}$, the home country produces only good $x$ (with output equal to $L / a_{x}$ ) and the foreign country produces none of it. Finally, if the relative price happens to equal the relative input requirements in one of the countries, then production of both goods will be (marginally) profitable in that country, and the supply of good I there will be infinitely price elastic within the range of outputs that can feasibly be produced. Taking all of this into account, the figure shows SS, the world supply curve for good $x$.

World demand for good $x$ can take any of the three positions labelled $D_{1} D_{1}$, $D_{2} D_{2}$, or $D_{3} D_{3}$. In the first and last of these, the share of world income spent on one or the other of the two goods is relatively high. Then one of the countries remains incompletely specialized in the free-trade equilibrium, while the other is active only in the sector in which it is relatively more productive. The free-trade relative price equals the relative input requirement of the country that remains incompletely specialized. Clearly, this country exports the good in which it enjoys a comparative advantage, because that good is consumed by its trade partner but not produced there.

The other type of equilibrium arises when a moderate share of world income is spent on both goods, so that world demand is as depicted by $D_{2} D_{2}$. Then both countries specialize in their production. The pattern of trade is immediate in this case.

The model can readily be extended to include more goods. ${ }^{2}$ It is simplest, in fact,

\footnotetext{
${ }^{2}$ It is also straightforward to expand the number of countries. With only two goods, all of the countries with the greatest comparative technological advantage in sector $z$ (i.e., those with the smallest values of $\left.a_{x} / a_{y}\right)$ produce and export this good, while the remaining countries produce and export good $y$ (see Becker [1952]). If all countries have different relative input requirements, then at
} 
to allow for a continuum of goods, as in Dornbusch, Fischer, and Samuelson (1977). Let the goods be indexed by $z \in[0,1]$ and let $a(z)$ and $a^{*}(z)$ be the unit labor requirements for producing good $z$ in the home and foreign countries, respectively. Order the goods so that $M(z) \equiv a(z) / a^{*}(z)$ is increasing in $z$, as shown in Figure 2. This means that for any two goods $z^{\prime}$ and $z^{\prime \prime}$, if $z^{\prime}<z^{\prime \prime}$ the home country has the greater relative technological advantage in producing $z^{\prime}$. Then, for any pair of wage rates in the two countries, the unit cost of producing good $z$ at home is less than the cost of producing that same good abroad if and only if $w a(z)<w^{*} a^{*}(z)$, or $M(z)<w^{*} / w$. Once we have determined the equilibrium relative wage, we will also know which goods are produced by each country; the home country produces all and only those goods for which $M(z) \leq w^{*} / w$.

To determine the relative wage we must specify the demand conditions. The simplest case is one in which all consumers have identical Cobb-Douglas preferences, spending the constant share $b(z)$ of their income on good $z .^{3}$ If the home country produces all of the goods with an index less than $z$, the share of world income devoted to its (aggregate) output is $B(z) \equiv \int_{0}^{z} b(s) d s$. This must match the value of its output, which, in a competitive equilibrium, equals its total wage bill. Thus $B(z)(w L+$ $\left.w^{*} L^{*}\right)=w L$, or

$$
\frac{w^{*}}{w}=\frac{L}{L^{*}} \frac{1-B(z)}{B(z)}
$$

We plot the right-hand side of (1) in Figure 2, and find the equilibrium wage at the intersection with the $M(z)$ curve. The equilibrium features a "chain" of comparative advantage, with the home country producing all of those goods for which its relative technological advantage is the greatest.

This simple continuum model gives sharp predictions about the static pattern of trade. It has been used extensively to study a number of important issues, including most one of them can be incompletely specialized in the free-trade equilibrium. The identity of the marginal country producing each good is determined by demand conditions. The model with more than two countries and goods is somewhat more complicated; see Jones (1961).

${ }^{3}$ Wilson (1980) treats the case with non-homothetic and non-identical demands. 
the gains from trade, the effects of technological progress, the interaction between monetary disturbances and international specialization, and the effects of environmental regulations on trade. We will illustrate some of these applications in sections 1.2 and 1.5 .

\subsection{Technology Gaps}

In the general Ricardian model, the pattern of relative technological capabilities is entirely arbitrary. As a consequence, the model has nothing to say about the type of goods in which a country with certain characteristics might be expected to export. To fully address this issue, it is necessary to endogenize the accumulation of technical know how, as we intend to do in the sections that follow. But even within the present paradigm it is possible to put more structure on the nature of technological differences across countries, in order to make the model consistent with observed patterns of trade.

For example, it is commonly noted that the more advanced countries typically produce and export the more technologically sophisticated goods. Krugman (1986) describes a model of "technology gaps" that has this feature. Suppose there is a "best-practice" labor requirement for producing good $z, \tilde{a}(z)$, that evolves according to $\check{a}(z)=e^{-g(z) t}$. Goods are ordered so that $g(z)$ is an increasing function of $z$. Then we can interpret $z$ as a measure of the technological intensity of a good, because goods with higher indexes experience more rapid technological progress. Now suppose that both home and foreign producers lag behind the technological frontier, but by differing a mounts. Let $\gamma$ and $\gamma^{*}$ be the respective technological lags. This means, for example, that a home firm can produce a unit of good $z$ at time $t$ with $a(z)=e^{-g(z)(t-\gamma)}$ units of labor. According to this formulation, the foreign country, which we take to be more "advanced" (i.e., $\gamma^{\bullet}<\gamma$ ), has an absolute advantage in producing all goods. But its comparative advantage lies in the more sophisticated goods, because the technological gap matters relatively least for the goods that experience the slowest technological progress. So the more technologically advanced country indeed produces and exports the more knowledge-intensive goods. 


\subsection{Product Cycles}

It has also been observed by Vernon (1966) and others that the North produces and exports the majority of newly invented goods. The South, meanwhile, specializes in goods that have been around for longer. This trade pattern emerges in Krugman's (1979) model of the "product life cycle", which emphasizes the slow diffusion of technologies from North to South.

Let consumers have the utility function $u=\left[\int_{0}^{\infty} c(z)^{\alpha} d z\right]^{1 / \alpha}, 0<\alpha<1$, that is defined over all existing and potential goods. Here $c(z)$ is consumption of good $z$. At time $t$ there are $n_{t}$ goods available and every pair of these has a constant elasticity of substitution $\sigma \equiv 1 /(1-\alpha)$. Now suppose that all innovation takes place in the North. At every moment Northern producers somehow acquire the additional knowledge needed to produce a certain number of new goods. Firms in the South, meanwhile, learn the methods of producing these goods only after a (random) adoption lag. This sequence of innovation in the North and diffusion to the South gives rise to a particular pattern of trade when the South has a cost advantage due to lower wages: the North enjoys comparative advantage in relatively new goods (those technologies that the South has not yet learned to produce), while the South has comparative advantage in older products whose technologies it has already mastered.

The static equilibrium can be described as follows. Let $n_{N}$ denote the number of goods that can only be produced in the North (at a moment in time) and let $n_{S}$ denote the number of goods that can be produced in both the North and the South. With perfect competition, the price of a good produced in country $j$ is $a w_{j}, j=S, N$, where $w_{j}$ is the country's wage rate. Using the assumed CES utility function, we can derive the relative demands for typical goods produced in the North and the South, $c_{N} / c_{S}=\left(w_{N} / w_{S}\right)^{-\sigma}$. Then, if the North manufactures all of the goods and only those goods that solely its producers know how to produce, labor-market clearing in each country entails $n_{j} c_{j}=L_{j}, j=S, N$. We can solve for the equilibrium relative wage that is implied by this hypothesis, namely $w_{N} / w_{S}=\left(n_{N} / n_{S}\right)^{1 / \sigma}\left(L_{N} / L_{S}\right)^{-1 / \sigma}$. For a range of values of $n_{N} / n_{S}$ and $L_{N} / L_{S}$, the implied relative wage exceeds one, which is all that we need to support the pattern of specialization that we have assumed. 
Krugman (1979) notes that the long-run relative wage of the North varies positively with its rate of new product development, but negatively with the rate of technological diffusion to the South. Yet, as Helpman (1993) points out, the North must benefit in welfare terms from an increase in the rate of technology transfer, at least if the initial diffusion rate is small.

\subsection{Many Factors of Production}

When there is more than a single factor of production and countries differ in their relative factor endowments, general propositions about the relationship between technology and the pattern of trade are harder to come by. As Jones $(1965,1970)$ has shown, technological differences must be gauged not only in terms of the sectorial advantages of one country vis-a-vis its trade partners, but also in terms of the factor bias of the technological superiority. For example, a country that has a capital-saving technological superiority in the labor-intensive production sector may find itself importing the labor-intensive good, even if $i t$ is relatively well endowed with labor compared to its trade partner.

Markusen and Svensson (1985) have examined the implications of (small) Hicksneutral technological differences between two countries that have similar factor endowments and tastes. Let the technology for producing good $z$ at home be $F_{z}\left(V_{z}\right)$, where $V_{z}$ is the vector of inputs used in producing good $z$ and $F_{z}(\cdot)$ is homogeneous of degree one. Suppose that the foreign technology differs slightly (i.e., by an arbitrary vector of infinitesimal deviations), and is given by $A_{z} F_{z}\left(V_{z}^{*}\right)$. Then it can be shown that $\sum_{z} A_{z} p_{z} m_{z}>0$, where $p_{z}$ is the price of good $z$ and $m_{z}$ is the home country's imports of this good. In other words, each country exports on average the goods in which it enjoys the relatively largest productivity advantages.

Small, Hicks-neutral technological differences also feature prominently in a recent paper by Davis (1994). Suppose there are two factors of production and two industries with differing factor intensities. The first industry produces a single good while the second produces a pair of goods that are imperfect substitutes. Then if the home country holds a small technological advantage in producing one of the two outputs 
of the second industry, it must produce all of the world's output of this good in any trade equilibrium with factor price equalization. It is likely that the other country will produce much or all of the other product of the second industry, especially if the two goods enter demand relatively symmetrically and the countries are of nearly equal size. In this case, small technological differences give rise to intra-industry trade in a world of perfect competition and constant returns to scale.

\subsection{Technical Progress and National Welfare}

Models of trade with exogenous technological differences can be used to study the effects of technical progress in one country on national welfare there and abroad. This line of inquiry dates back at least to Hicks (1953), who introduced the useful distinction between "export-biased" and "import-biased" technological change.

The basic ideas can be illustrated most readily in the simplest Ricardian model with two goods. Suppose first that the home country is incompletely specialized, while the foreign country specializes in producing good $x$. Import-biased technical progress reduces the labor requirement in the home country's import-competing sector. Take the foreign wage rate as numeraire (i.e., $w^{-}=1$ ). Then the price of good $x$ must remain fixed at $p_{x}=a_{x}^{*}$. Since $p_{x}=w a_{x}$, the home wage rate rises in proportion to the fall in the input requirement; i.e., $\dot{w}=-\hat{a}_{x}$, where a circumflex indicates a proportional change. So the price of good $y$, which equals its unit cost of production $w a_{y}$, rises in response to the import-biased technological progress. In short, the home country's terms of trade improve. It follows that the home country must benefit from this form of technological progress, while its trade partner must be harmed by the change.

Now consider export-biased technical progress. For this purpose, it is best to focus on an initial equilibrium with specialization in both countries. It is necessary to take a particular form for consumer utility in order to evaluate the welfare changes. We assume for this purpose that $U=\left(c_{x}^{\alpha}+c_{y}^{\alpha}\right)^{1 / \alpha}$; i.e., consumers perceive a constant elasticity of substitution $\sigma \equiv 1 /(1-\alpha)$ between the two goods. With these preferences, the share of individual (and world) income devoted to good $x$ is 
$b_{x}=p_{x}^{1-\sigma} /\left(p_{x}^{1-\sigma}+p_{y}^{1-\sigma}\right)$. For concreteness, suppose that the foreign country produces good $x$, and again take its wage as numeraire. Then $p_{x}=a_{x}^{*}$ is unaffected by the productivity gain in the home country. Since the share $b_{x}$ of world spending goes to good $x$, equilibrium requires $\left(w L+L^{*}\right) b_{x}=p_{x} L^{*} / a_{x}^{*}$. We can use these equations to calculate the equilibrium change in the home country's wage rate and, from that, the change in $p_{y}{ }^{4}$

Stability of world markets requires the price of good $y$ to fall in response to an exogenous increase in its supply. Thus, the home country suffers a deterioration of its terms of trade in response to its export-biased technological progress. This movement in the terms of trade offsets the direct gain from the productivity increase. The question that arises is: Can a country that sees its production methods improve actually be harmed by the technological advancement? In our example the change in real income is given by $\hat{U}=\hat{w}-b_{x} \dot{p}_{x}-b_{y} \dot{p}_{y}$. It is straightforward to show that "immiserizing growth" can indeed occur in a stable equilibrium, and does so if and only if $\sigma<b_{x}$. Intuitively, the home country's terms of trade deteriorate most when the two goods are poor substitutes, while the home residents benefit least as consumers from the fall in the relative price of good $y$ when good $x$ comprises the bulk of their consumption basket. ${ }^{5}$

The effects of technological divergence and convergence across countries can be captured in Krugman's (1986) model of technology gaps. Suppose that the adoption lag shrinks in the country that already has the shorter lag, thereby widening this country's technological lead. Such technical change is export biased, because the fall in production costs is proportionally greatest in the most knowledge-intensive

\footnotetext{
1From the equilibrium requirement we calculate $\hat{b}_{z}+\left(1-b_{z}\right) \dot{w}=0$, where we have used the fact that the share of spending devoted to good yequals the share of the home country in world income, in view of the complete apecialization by both countries. Also, from the definition of $b_{z}$ and the fact that $p_{y}=w a_{y}$, we find that $\dot{b}_{x}=\left(1-b_{z}\right)(\sigma-1)\left(\bar{w}+\dot{a}_{y}\right)$. These two equations enable us to sove for the proportional rate of change of the wage rate and the price of good $y$ in response to an exogenous change in $a_{y}$.

${ }^{5}$ Bhagwati $(1958 a, b)$ coined the term immiserizing growth and explained how it could arise in the face of adverse movements in the terms of trade. The equations derived in the previous footnote can be used to derive the condition for immiserizing growth given in the text.
} 
sectors, where the country already holds its comparative advantage. Using a diagram like Figure 2, we can see that the relative wage of the advanced country must rise while the range of goods that it produces expands. But then the relative wage increase must be proportionally smaller than the productivity gain in the original marginal sector, and a fortiori in the other sectors with even greater knowledge intensities. As a result, the lagging country sees its terms of trade improve (the prices of all goods originally produced by the leading country fall relative to the prices of all goods originally produced by the lagging country) and its welfare rise. The advanced country also must gain in this case, because its real wage rises in terms of the products it originally produced (since productivity has improved), in terms of the products that it ultimately imports (since the relative wage gap widens), and in terms of the goods that it begins to produce (since these goods would have become cheaper in terms of the advanced country's labor had the other country continued to produce them, and the shift in production to the new low-cost location reduces their price even more).

Now consider technological "catch-up" by the less advanced country. Such learning is import biased; i.e., it reduces costs the most for the goods that the lagging country initially imports, including those that are at the margin of competitiveness between the two countries. The range of goods produced in the lagging country expands while its relative wage rises. The lagging country's welfare must improve, because its real wage rises in terms of all goods. But the advanced country may suffer from the narrowing of its technological lead. The goods that it formerly produced but now imports are cheaper relative to its own wage rate (or else the location of production would not have changed), but the goods that it imports before and after the gap closes are more expensive due to the adverse movement in its terms of trade.

Finally, Findlay and Grubert (1959) have studied the terms-of-trade effects of technological progress in a world of two goods and two factors of production. Hicksneutral technological progress in a country's import-competing sector must improve its terms of trade, while the same form of technological progress in the export sector has just the opposite effect. This is because, at constant prices, Hicks-neutral advancement always expands relative output in the sector that experiences the productivity 
gain, and so the price of this good must fall to restore a stable, global equilibrium. In contrast, capital-using technological progress in a capital-intensive export industry may improve the terms of trade, while labor-using progress in a labor-intensive import-competing industry may cause the terms of trade to deteriorate. In these two cases, the factor bias in the technological change works against the direct effect of the productivity gain by making relatively more scarce the factor used intensively in the advancing sector's production. If the induced change in relative factor prices is large enough, the relative output of the advancing sector may fall at constant prices even though its technology has improved. Then the relative price will move in favor of the advancing sector.

It is apparent from our review that models with exogenous differences in technological capabilities have much to offer trade theory. These models provide clear insights into important policy issues at relatively low cost in terms of technical complexity. Still, they are rather limited in what they can teach us, because they fail to identify the primitive sources of national competitiveness. We turn now to the recent developments in the theory that allow us to address issues having to do with the endogenous creation of comparative advantage

\section{Learning by Doing}

While technological progress sometimes happens serendipitously, more often it is a consequence of economic activity. Two modes of learning seem most prevalent in commercial enterprises. Some learning occurs as a by-product of activities undertaken for other purposes. In particular, firms often discover better ways of doing things in the course of producing output or installing capital. Other learning is the result of more deliberate efforts to create knowledge. This section focuses on the relationship between international trade and incidental learning, while the next treats purposive in vestments in the acquisition of knowledge.

Where a learning curve applies to a single plant or firm, the distinction between 
learning-by-doing and more formal R\&D activities may not be so important. In both cases the firm recognizes a cost of creating knowledge, which it weighs against the potential benefits of a new or improved technique or product. But where the benefits that derive from experience spill across firms-as when knowledgeable workers move between rival producers or when the expertise accumulated by a company can be gleaned by inspecting its products-the evolution of technology may reflect decisions taken with quite different objectives in mind. In this section we focus on learning that occurs not only "by doing", but also "by accident".

Once we recognize that firms may gain knowledge from the experience of others, a question that arises is: What is the set of others from which a given firm learns? There are at least two dimensions to this question. First, does a firm in a given industry acquire technical information from the activities of local firms in other industries? Second, does it gain such information from the activities of firms in its own industry operating in other countries? These are empirical matters that obviously may vary with the particular context one has in mind. ${ }^{6}$

It is useful to begin with a unified perspective from which the various special cases can be analyzed and compared. To this end, suppose again that all outputs are produced by labor alone and that production everywhere exhibits constant returns to scale. But now suppose that the labor necessary to produce a unit of good $i$ in some country depends not only on the intrinsic productivity of the country's labor in producing that good, but also on the accumulated knowledge available there for manufacturing the product. In particular, let the production function take the form

$$
Z_{i}=A_{i}(\cdot) \frac{L_{i}}{a_{i}}
$$

where $L_{i}$ denotes the labor used in producing good $i, 1 / a_{i}$ measures intrinsic productivity, and $A_{i}(\cdot)$ is the relevant index of technical know how. In the models that we

\footnotetext{
${ }^{6}$ As an example, Irwin and Klenow (1993) have investigated the existence and geographic scope of knowledge spillovera from learning by doing in the semi-conductor industry. They find that firms indeed learn from the experience of others, and that learning spills over as much across borders as it does between firms located in the same country.
} 
will consider in this section, knowledge accumulates in the course of manufacturing output. The most general specification would make $A_{i}$ a function of the experience in each country at producing every one of the different goods. Rather than treat this general case, we will highlight various special cases in which spillovers are limited in some way, for example to firms operating in a given industry or cluster of industries, or to firms operating in a given country. This will allow us to isolate the specific implications of each new assumption.

\subsection{Complete International Spillovers}

To begin with, suppose that technical information flows readily across international borders. In the most extreme case, the experience of home producers contributes as much to the knowledge base abroad as it does to that at home. We take learning to be external to any individual firm but specific to its industry and proportional to cumulative industry output. Then, with two countries, $A_{i}=A_{i}^{*}=\delta_{i}\left(Q_{i}+Q_{i}^{*}\right)$, where $Q_{i}(t) \equiv \int_{\infty}^{t} Z_{i}(s) d s$ is cumulative output of good $i$ at home and $Q_{i}^{*}(t) \equiv \int_{\infty}^{t} Z_{i}^{*}(s) d s$ is cumulative output of the good abroad.

In this case, the relative labor requirement for producing a unit of good $i$ at home versus abroad equals $a_{i} / a_{i}^{*}$ at every moment in time. Evidently, learning neither strengthens nor weakens the forces of intrinsic comparative advantage. Intuitively, when producers in both countries share access to the same body of technical informa. tion, the accumulation of knowledge does not affect their relative abilities to produce any good. The trade pattern must be determined by other considerations.

This conclusion applies to a broader set of circumstances. For example, if countries have similar intrinsic abilities but different endowments of several factors of production, then Heckscher-Ohlin-like considerations dictate the pattern of trade. Our dynamic result mirrors Ethier's (1982a) finding that trade patterns are determined by traditional, comparative cost considerations when there are static increasing returns to scale emanating from international external economies.

Although technological progress has no bearing on comparative advantage when spillovers are global in their scope, trade may affect national rates of productivity and 
output growth in the short and long run. To illustrate this, we develop an example where, for certain parameter values and initial conditions, trade causes growth to slow in one or both trading economies. To this end, consider once again a world economy with two goods, $x$ and $y$, in which consumers have the CES preferences $u=\left(c_{x}^{\alpha}+c_{y}^{\alpha}\right)^{1 / \alpha}$. Recall that $\sigma=1 /(1-\alpha)$ is the elasticity of substitution and suppose that $\sigma>1$. In autarky, each country eventually specializes in producing one good or the other (at least, asymptotically), where the sector of eventual concentration depends on intrinsic abilities and initial conditions. Take, for instance, the home country. Its relative autarky outputs, $x / y$, must satisfy relative demands, $\left(p_{x} / p_{y}\right)^{-\sigma}$, at the prevailing relative prices, $p_{x} / p_{y}=S a_{x} / a_{y}$. Here $S \equiv A_{y} / A_{x}$ denotes the ratio of the stocks of knowledge capital in the two industries. Using the production functions for $x$ and $y$ analogous to (2), we can solve for the momentary employment level in each industry. Then we can calculate output levels in each sector and so the additions to experience and to the stocks of knowledge. We find that

$$
\hat{S}=\frac{L}{1+S^{1-\sigma}}\left[\frac{\delta_{y}}{a_{y}}-\frac{\delta_{x}}{a_{x}} S^{1-\sigma}\right] .
$$

The dynamics represented by equation (3) are globally unstable when $\sigma>1$. So $S$ tends to infinity or zero as the initial ratio of knowledge stocks exceeds or falls short of $\left[\left(\delta_{x} / a_{x}\right) /\left(\delta_{y} / a_{y}\right)\right]^{1 /(\sigma-1)}$. If $S$ approaches zero, the fraction of the labor force employed in sector $y$ does likewise, while if $S$ approaches infinity, the fraction of the labor force employed in sector $y$ approaches one. The long-run autarky growth rate of output is $L \delta_{x} / a_{x}$ in the former case and $L \delta_{y} / a_{y}$ in the latter.

Now suppose that the two countries trade. For concreteness, assume that the home country has comparative advantage in producing good $x$. This means, as we have seen, that its relative intrinsic productivity in this sector exceeds that in the foreign country. Also, let the initial equilibrium involve complete specialization in both countries. Then as long as both countries remain completely specialized, $\hat{A}_{x}=\delta_{x} L / a_{x}$ and $\hat{A}_{y}=\delta_{y} L * / a_{y}^{*}$. So $\hat{S}=\delta_{y} L / a_{y}-\delta_{z} L_{x}^{*} / a_{x}^{*}$, which may be positive or negative. If it is positive, then eventually the home country will find it profitable to begin producing good $y$, whereupon relative productivity in that sector will accelerate further. On 
the other hand, if $\hat{S}$ is negative, then eventually the foreign country will find it profitable to produce good $x$, and the relative productivity of sector $y$ will decline more rapidly. In the long run, both countries specialize in producing whichever good initially experiences the more rapid productivity growth.

Notice that trade may lead one or both countries to specialize in a good different from the one in which it specialized in autarky. Suppose this is true of the home country, which specialized, say, in producing good $x$ in autarky but ultimately switches to producing good $y$ after the opening of trade. Then, if $\delta_{x} L / a_{x}>\delta_{y}\left(L / a_{y}+L^{*} / a_{y}^{-}\right)$, trade effects an eventual slowing of this country's growth rate. ${ }^{7}$ If the foreign country also happens to specialize in producing good $x$ in autarky and if $\delta_{x} L^{*} / a_{x}^{*}>$ $\delta_{y}\left(L / a_{y}+L \cdot / a_{y}^{*}\right)$, then this country too will experience a slowdown in growth as a result of trade. Here, comparative advantage determines the initial pattern of specialization when trade begins, but then absolute productivity and the size of each country determine how rapidly experience accumulates in each sector. If the country that has comparative advantage in the sector with the lesser long-run growth prospects happens to be larger or more intrinsically productive, trade can tilt the equilibrium growth path in the "wrong" direction [see Yanagawa (1993)].

On the other hand, if the countries ultimately specialize in producing the same good with trade as they did in autarky, or if the two sectors do not differ greatly in their growth potential (e.g., if $\left.\delta_{x}\left[L / a_{x}+L * / a_{z}^{*}\right]=\delta_{y}\left[L / a_{y}+L^{*} / a_{y}^{*}\right]\right)$, then trade must boost the long-run growth rate in each country. This is because the longrun trade equilibrium has both countries concentrating their production in the same industry, and knowledge accumulates more rapidly when the experiences of two sets of producers contribute to learning instead of just one. Even so, one of the countries may suffer a deceleration of its growth in the short or medium run. Suppose, for example, that both countries produce good $x$ in autarky and that both also will produce this good (which, say, has greater growth potential) in the long-run trade equilibrium. The foreign country may nonetheless experience a period where it specializes in the

\footnotetext{
${ }^{7}$ If both countries specialize in producing good $i$, world output of this good amounts to $A_{i}\left(L / a_{i}+\right.$ $\left.L a_{i}^{*}\right)$. Then $\delta_{i}\left(L / a_{i}+L L^{*} / a_{i}^{*}\right)$ gives the proportional rate of productivity and output growth.
} 
production of good $y$, as a result of its comparative advantage in producing that good. In the event, the opening of trade may have an adverse impact on its growth rate during the initial phase of the trading era.

\subsection{National Spillovers}

Most of the literature, beginning with Bardhan (1970), assumes that companies learn more from the experiences of other domestic producers than they do from firms located abroad. To understand the implications of having learning spillovers that are limited in their geographic reach, we consider the extreme case of national learning; that is, we posit industry-specific knowledge stocks that accumulate in proportion to local industry activity alone. With the same notation as before, $A_{i}=\delta_{i} Q_{i}$ and $A_{i}^{*}=\delta_{i} Q_{i}^{*}$.

Krugman (1987) studies a world economy with two countries and a continuum of industries. He takes preferences to be Cobb-Douglas, so that the initial equilibrium is determined as in Figure 2. Then, if industries are arranged in order of decreasing relative productivity advantage for the home country at time 0 , the home country initially produces all goods with indexes below some critical number. Over time, learning by doing makes the home producers even more productive in each of the goods initially manufactured at home, while foreign producers gain no experience in these sectors. Therefore, the relative productivity advantage of the home country in each of these industries grows over time. Similarly, foreign firms gain experience and knowledge in producing the range of goods initially manufactured abroad, while home firms learn nothing in these industries. This widens the foreign relative productivity advantage of its export sectors. In short, the analog to the $M(z)$ schedule in Figure 2 becomes steeper over time, and the initial pattern of trade gets "locked in." Since the initial pattern of specialization depends not only on intrinsic ability but also on the initial stocks of industry knowledge in each country, history matters for the determination of the long-run trade pattern.

Lucas (1988) treats a similar model, but with two goods, CES preferences, and a continuum of small countries. Suppose all countries have the same labor force $L$ 
and the same intrinsic abilities $1 / a_{x}$ and $1 / a_{y}$, but they differ in their initial stocks of knowledge capital. Then those with the highest ratios $A_{x} / A_{y}$ at time 0 initially produce good $x$ and the remaining countries initially produce good $y$. Will any country have an incentive to switch as time passes? To answer this question, we note that productivity grows at the rate $\delta_{x} L / a_{x}$ in each country that produces good $x$. World output of this good expands at this same rate, assuming that no country changes its sector of specialization. Similarly, productivity grows at the rate $\delta_{y} L / a_{y}$ in the typical country producing good $y$, and aggregate output of this good grows at the same rate under our working hypothesis. Let's assume for concreteness that $\delta_{x} / a_{x}>\delta_{y} / a_{y}$, so that the relative output of good $x$ is increasing over time and its relative price is falling. Then, if any country will switch its industry of specialization, it must be the marginal country that produces good $x$. But competitive producers will switch from producing good $x$ to producing good $y$ in this country only if the rate of price decline exceeds the rate at which productivity expands in sector $x$ (since productivity in sector $y$ is stagnant so long as none of this good is being produced). The relative price of good $x$ falls at the rate $L\left(\delta_{x} / a_{x}-\delta_{y} / a_{y}\right) / \sigma .^{8}$ With $\sigma>1$, this never exceeds the rate of productivity growth. So, again, the initial pattern of trade gets locked into place.

It can readily be shown that the countries that specialize in producing good $x$ in the trade equilibrium experience faster real income growth than those that specialize in producing good $y .{ }^{9}$ This raises the possibility that some countries might wish to use trade or industrial policies to alter their patterns of specialization. Indeed a small country that specializes in the slower-growing sector in the absence of any policy intervention but that is close to the margin of competitiveness in the faster-growing sector would gain from any policy that induced its producers to switch over to the other good. The short-run income loss for such a country would be small, while the

\footnotetext{
${ }^{8}$ The CES preferences give rise to a constant elasticity of demand, so relative price movements are related to relative quantity changes according to $\dot{Z}_{y}-\dot{Z}_{y}=\sigma\left(\hat{p}_{z}-\hat{p}_{y}\right)$. The expression in the text follows from the fact that aggregate output of good $j$ grows at rate $\dot{Z}_{j}=L \delta_{j} / a_{j}$, for $j=x, y$.

${ }^{9}$ Matsuyama (1992) makes a similar point in a model with specific factors in each sector, where countries remain incompletely specialized.
} 
policy would generate a permanent boost to its productivity growth. Moreover, the government intervention would only be needed for a short time, until the country had collected enough experience in its new area of specialization to overcome its initial comparative disadvantage in this sector. Policy here can correct the inefficiency that results from producers' failure to account for the externalities associated with their production decisions. ${ }^{10}$

Krugman (1987) makes a slightly different point about policy in his analysis of two large countries trading a continuum of goods. Each country then has an incentive to subsidize production of a few goods near the margin of competitiveness, so that it can gain experience and take over production of these goods. By doing so, it expands the range of products it manufactures, increases demand for its labor, and betters its terms of trade. Again, the requisite subsidy need be in place for only a short time, as producers soon will accumulate the knowledge to make up for any deficiency in intrinsic ability or initial experience. The incentive to slice off new sectors a few at a time continues for a while (Krugman refers to this as the "narrow moving band"), but eventually the wage differential between the countries becomes sufficiently large that the social cost of capturing the next industry exceeds the benefit.

\subsection{Inter-industry Spillovers}

Firms sometimes enjoy learning spillovers from the experiences of other firms producing entirely different goods. Moreover, the activities undertaken in certain industries may be especially conducive to generating ideas with widespread potential for improving productivity, while those performed in others may be more mundane and thus contribute little to the accumulation of knowledge. Boldrin and Sheinkman (1988) and Grossman and Helpman (1990b) have examined the implications of intersectoral learning-by-doing, where various industries do not contribute equally to the creation of knowledge.

\footnotetext{
${ }^{10}$ Bardhan (1970) studied the time pattern of the optimal subsidy to production in a small country that benefits from learning by doing in only one sector and that initially produces both goods, because it has two inputs and the sectors have different factor intensities.
} 
Let us again examine an extreme case, this time assuming that learning takes place only in the course of producing good $x$. Let the knowledge so generated bolster productivity equally in each of two sectors. In particular, take $A_{i}=\delta Q_{x}$, for $i=$ $x, y$. Suppose, moreover, that each industry uses a non-accumulable specific input, in addition to labor, so that there are strictly decreasing returns to labor in any one activity at every moment in time. This will allow a long-run equilibrium with active production in both sectors. We denote the production functions for goods $x$ and $y$ by $A_{x} F_{x}\left(L_{x}\right)$ and $A_{y} F_{y}\left(L_{y}\right)$, respectively. The functions $F_{x}(\cdot)$ and $F_{y}(\cdot)$ may differ across countries, if the countries happen to have different stocks of the sector-specific factors.

Consider again a world economy with a continuum of small countries. At every moment in time, competition drives each country to produce where the ratio of the marginal products of labor in the two industries, $F_{y}^{\prime} / F_{x}^{\prime}$, equals the world relative price of good $x$. Then knowledge accumulates at the rate $F_{x}\left(L_{x}\right)$, and output and productivity grow in each sector at this rate. Since only experience in sector $x$ generates technological progress, growth proceeds faster the greater are the resources devoted to this activity in the trade equilibrium. Evidently, countries with a natural comparative advantage in producing good $x$ will grow faster than those with endowments suitable for producing good $y$. Moreover, if a country happens to accumulate more of the factor specific to industry $y$ or if it somehow experiences an exogenous productivity improvement in this sector, its growth will slow and its aggregate welfare may fall [see Grossman and Helpman (1990b) and Matsuyama (1992) for further discussion].

\subsection{Industry Clusters}

Posner (1961) was the first to note that "clusters" of industries might migrate together to particular nations. This dynamic process would occur, he argued, if learning-bydoing generated knowledge spillovers within but not between the clusters and if these spillovers were limited in their geographic reach. We will illustrate here how clustering might happen, without providing a general analysis. 
Suppose that there are two distinct industry clusters, each comprising two goods. Let consumers worldwide devote constant and equal shares of their spending to each of the total of four goods. In the home country, one unit of labor can produce $A_{; j}$ units of good $i$ in cluster $j$ at a given moment in time. The corresponding (time-varying) productivity parameters for the foreign country are denoted by $A_{i j}^{*}$. We assume that the home country initially has an absolute advantage in producing the first good in each cluster $\left(A_{1 j}>A_{i j}^{*}\right.$ for $\left.j=1,2\right)$ and that the foreign country has an absolute advantage in producing the second good in each cluster $\left(A_{2 j}^{*}>A_{2 j}\right.$ for $\left.j=1,2\right)$. But we also suppose that $A_{11}>A_{21}^{*}$ and $A_{22}^{*}>A_{12}$; i.e., the home country's initial productivity advantage in the first good of cluster 1 exceeds the foreign country's productivity advantage in the second good of that same cluster, whereas the opposite is true for cluster 2. Finally, we assume that productivity improves with national experience in producing any good in a cluster; i.e., $d A_{i j} / d t=X_{j}$ and $d A_{i j}^{*} / d t=X_{j}^{*}$, where $X_{j}=\Sigma_{i} X_{i j}$ and $X_{j}^{*}=\Sigma_{i} X_{i j}$ are aggregate home output and aggregate foreign output in cluster $j$, respectively.

Let the two countries have the same labor force $L$. Then the initial equilibrium has the home country producing the first good in each cluster and the foreign country producing the second good in each cluster, in accordance with the dictates of (initial) comparative advantage. In this equilibrium, the wage rates in the two countries are equal. ${ }^{11}$ Home output in cluster 1 amounts to $X_{1}=X_{11}=A_{11} L / 2$, which exceeds foreign output in that cluster, $X_{1}^{*}=X_{21}^{*}=A_{21}^{*} L / 2$. So home productivity in manufacturing the two goods of cluster 1 initially grows faster than does foreign productivity. Similarly, foreign productivity grows faster in cluster 2 , as the foreign country produces a greater quantity of output there. It is this differential in national productivity growth rates that gives rise to the possibility of industry clustering.

In our example, eventually either $A_{21}$ catches up with $A_{21}^{*}$, or else $A_{12}$ catches up with $A_{12}$. That is, either the rapid home productivity growth in cluster 1 eliminates

\footnotetext{
${ }^{11}$ When the home country produces all of world output of exactly two goods, the share of world spending devoted to its product is one half. World spending on home goods thus amounts to $\left(w L+w^{*} L^{*}\right) / 2$, where $w$ and $w^{*}$ are the horne and foreign wage rates, respectively. This must equal the value of home output, $w L$, which imlies $w=w^{\bullet}$ in view of the fact that $L=L^{\bullet}$.
} 
the foreign country's initial productivity advantage in producing the second good in this cluster, or else the rapid foreign productivity growth in cluster 2 eliminates its initial disadvantage in producing the first good of that cluster. Suppose, for concreteness, that the former event happens first. Then, at the moment that the two productivity parameters become equalized $\left(A_{21}=A_{21}^{*}\right)$, the home country commences production of the second good in cluster 1 and the home wage begins to rise above the foreign wage. ${ }^{12}$ There ensues a period during which $w / w^{*}=A_{21} / A_{21}^{*}$ and both countries produce the second good of cluster 1 . During this period, the home country's market share in this good increases over time. During this period, also, the foreign country sees a (continued) narrowing of its relative cost disadvantage in producing the first good of cluster 2. This narrowing occurs now for two reasons. First, the foreign country continues to produce more output in cluster 2 , so its productivity grows faster than that in the home country. Second, the rising relative wage of the home country enhances foreign relative competitiveness in all industries, given the productivity levels. Eventually, there comes a time when $w / w^{*}=A_{12} / A_{12}^{*}$, whereupon firms in the foreign country find it profitable to begin production of the first good of cluster $2 .{ }^{13}$ Thereafter, the wage gap between the countries narrows while the foreign country's share of world production of good $X_{12}$ grows, until in the long run the wage rates are again equalized and each country specializes in producing both of the goods in one of the two industry clusters.

The explanation for the clustering of goods here is apparent. If a country initially produces a large quantity of any one good in a cluster, then the learning spillovers from this activity will tend to confer a dynamic comparative advantage in other industries in the same cluster, even if productivity in those other industries initially

\footnotetext{
${ }^{12}$ If the home wage did not rise above the foreign wage, the home country would immediately have a cost advantage in producing three of the goods. But with three quarters of world spending devoted to its goods and the value of spending on home goods equal to the value of output, we could not have $w=w^{*}$.

${ }^{13}$ Before this happens, there may or may not occur a period during which the home country produces all of world output of the second good in cluster 1 and the relative wage between countries remains constant for a time.
} 
is low. In our example, the large initial outputs resulted from an assumed pattern of absolute productivity differentials. But a similar dynamic would arise if, for example, demands for the various goods were asymmetric. Then, a country that has an initial comparative advantage in producing the most popular good or goods in a cluster would tend, over time, to gain competitive advantage in producing the remaining, less-popular goods.

\subsection{Bounded Learning}

In all of the settings we have examined thus far, indefinite productivity growth has been possible due to unbounded opportunities for learning by doing. Yet, as Young (1991) points out, the empirical evidence points to strongly diminishing returns to this type of learning, at least where any particular manufacturing process is concerned. Diminishing returns set in, presumably, because fresh insights are more difficult to come by once a given activity has been repeated a large number of times. ${ }^{14}$ But Young (1991) and Stokey (1991) have shown that productivity growth may be sustained in the long run, despite the boundedness of opportunities for learning in every sector, provided that there are sufficient spillovers of knowledge from each activity to some others with more long-run potential for contributing to well-being.

In order to illustrate their point, we introduce two new forms for consumers' preferences. These are

$$
u=c_{0}^{l-\mu}\left[\sum_{i=1}^{\infty} \lambda^{i} c_{i}\right]^{\mu}, \quad \lambda>1, \quad \mu>1 / 2,
$$

and

$$
u=c_{0}\left[\sum_{i=1}^{\infty} \lambda^{i} \log \left(1+c_{i}\right)\right], \quad \lambda>1,
$$

where $c_{0}$ is consumption of a numeraire good 0 and $c_{i}$ is consumption of good $i$. If

\footnotetext{
${ }^{14}$ Bardhan (1970, p.112-3) also recognized the possibility that opportunities for learning by doing might be bounded. He examined the implications of this for the time path of the optimal production subsidy.
} 
consumers have the first of these two utility functions, they view all products except the numeraire good as perfect substitutes, but see products with higher indexes as contributing greater utility per unit of consumption. If they have the second set of preferences, they again see products with higher indexes as more desirable, but view the non-numeraire goods as imperfect substitutes while showing a taste for diversity in consumption. In either case, technological progress may take the form of improvements in the techniques for producing a given set of goods or the replacement of some goods by others of higher "quality".

We now suppose that the opportunities for learning by doing are bounded for any product but that spillovers take place from one industry to another. In particular, the act of producing any "generation" of product contributes information that helps firms to better produce that generation and the next. More formally, we assume that one unit of labor can produce one unit of the numeraire good and $A$; units of good $i$, where $Q_{i-1}=0$ implies $A ;=0$ and $Q_{i-1}>0$ implies

$$
A_{i}=A_{0}+\beta \min \left(Q_{i-1}, \bar{A}-A_{0}\right)+(1-\beta) \min \left(Q_{i}, \bar{A}-A_{0}\right)
$$

This means that goods must be introduced in order; i.e., the production of good $i$ remains infeasible until some positive amount of good $i-1$ has been produced. Once the production of a good becomes possible, labor productivity starts at $A_{0}$ and improves with experience in producing either the good before it on the quality ladder or the good itself. When the productivity level reaches $\bar{A}$, the opportunities for learning about the good are exhausted.

Consider first a closed economy in which households have the preferences given by (4). We will show that, with certain parameter restrictions, there exists a steadystate equilibrium in which utility grows indefinitely and new goods replace older ones at regular intervals. We do this by construction. Suppose that, at some moment, the economy produces the numeraire good and good $i$, and that experience in producing good $i-1$ had accumulated to $Q$, before production of that good had ceased. Assuming that there exists a periodic steady state, good $i$ should also be replaced by good $i+1$ when cumulative experience in the former reaches $Q_{\iota}$. Consumers begin to buy good $i+1$ at the moment when its price falls to a level only $\lambda$ times as great 
as that of good $i$. This requires, in a competitive market, that the productivity of labor in producing good $i$ be only $\lambda$ times as great as that in producing good $i+1$. In other words, we need $A_{0}+Q_{s}=\lambda\left(A_{0}+\beta Q_{s}\right)$, for good $i+1$ to become competitive at precisely the right moment. The solution to this equation gives a positive value for $Q_{\mathbf{s}}=(\lambda-1) A_{0} /(1-\lambda \beta)$, provided that $\beta<1 / \lambda$. We also require that good $i+2$ not be competitive at the moment after good $i+1$ is introduced. Consumers will not purchase good $i+2$ at this moment if its price exceeds $\lambda$ times the price of good $i+1$;

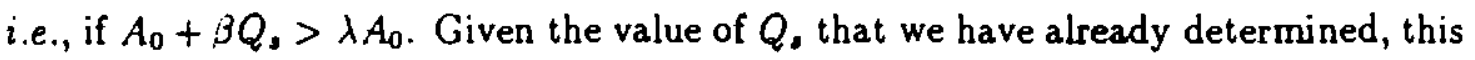
inequality is satisfied for $\beta>1 /(1+\lambda)$. Finally, the steady state we have described can obtain only if learning in good $i+1$ has been introduced before learning in good $i$ has been exhausted; that is, if $Q_{0}<\tilde{A}-A_{0}$.

Under the parameter restrictions just described, a periodic steady state exists. In the steady state, the wage rate remains fixed at one. Households spend a fraction $1-\mu$ of their income of $L$ on purchases of the numeraire good and the fraction $1-\mu$ of the labor force is employed producing this good to meet their demands. The remaining fraction $\mu$ of the labor force produces a "current generation" of knowledgeintensive products. Each generation is replaced by the next as soon as experience in the current product provides enough technical information to make its successor economically viable. As in Young (1991) and Stokey (1991), knowledge spillovers from one industry to the next sustain productivity growth in the long run.

Now let us reintroduce trade between two countries that are in every way identical except that the home country initially is less advanced in its production of the nonnumeraire good. We assume that the foreign country has accumulated experience in producing good $i^{*}$, while the home country has only produced goods up to $i, i<i^{\bullet}$. We will establish that, in the steady state of the trade equilibrium, the (lagging) home country specializes in producing the numeraire good while the (advanced) foreign country produces a succession of knowledge-intensive products introduced at regular intervals. Thus trade retards growth in the country that begins behind.

Again we proceed by construction. If the home country produces the numeraire good, then its wage rate must equal one. Moreover, if this country specializes in 
producing the numeraire and the foreign country produces none of it, then total output of this good and the total wage bill amount to $L$. Since a fraction $1-\mu$ of world spending is devoted to the numeraire good, the matching of revenues and costs implies $L=(1-\mu)\left(L+w^{*} L^{*}\right)$, or $w^{*}=\mu /(1-\mu)$ whenever $L=L^{*}$. Note that this gives $w^{*}>1$ when $\mu>1 / 2$; i.e., when there is sufficient demand for the non-numeraire good. In the event that $w^{*} .>1$, the foreign country indeed is uncompetitive in producing the numeraire good.

We know also that the knowledge available for producing good $i$ at home is at most $A_{0}+Q_{s}$, while that available for producing good $i^{*}$ abroad is at least $A_{0}+\beta Q_{s}$. Recognizing that the wage rate in the foreign country is higher than that at home, consumers will nonetheless prefer the foreign good of generation $i^{*}$ to the home good of generation $i$ if $\lambda^{i^{*}}\left(A_{0}+\beta Q_{0}\right) / w^{*}>\lambda^{i}\left(A_{0}+Q_{0}\right)$, or

$$
\lambda^{i-i^{*}}>\frac{A_{0}+Q_{0}}{A_{0}+\beta Q_{0}} \frac{\mu}{1-\mu} .
$$

If inequality $(6)$ is not satisfied at time 0 , then the home country produces some knowledge-intensive goods at first. But since it also produces all of the world's output of the numeraire good, it must devote less labor to the sector with learning than its trade partner and so its experience accumulates less rapidly. Over time, the technological gap between the two countries widens and eventually it becomes so wide that an inequality like $(6)$ is satisfied. Then the home country terminates its production in the knowledge-intensive sector forever. The conclusion is much the same as in Young (1991): trade causes the more advanced country to specialize in producing the goods that generate the most learning and accelerates productivity growth in that country. Meanwhile, the lagging country finds itself specializing in goods where learning opportunities are fewer (or, as here, absent), and so its growth slows. ${ }^{15}$ The more advanced country must gain from trade, but the less advanced country may gain or lose.

\footnotetext{
${ }^{15}$ Here, as in Young (1991), an initially lagging country that is larger than its trade partner can sometimes overcome its technological disadvantage and eventually capture the technologically progressive industry.
} 
The equilibria described so far have the unrealistic feature that the switch from one generation of good to the next occurs quite abruptly. The alternative preferences given by (5) generate a more gradual transition. For certain parameter values there exists a steady state in which the economy passes through a succession of phases in which: (i) only generation $i$ of the knowledge-intensive good is produced; (ii) generations $i$ and $i+1$ are produced; (iii) learning by doing becomes exhausted in the production of good $i$; and (iv) production of good $i$ ends and only good $i+1$ is produced.

We construct such an equilibrium for a closed economy. The country devotes $L / 2$ units of labor to producing the numeraire good and the remaining $L / 2$ units to the set of sectors where learning is possible. The prices of the knowledge-intensive goods of generations $i$ and $i+1$ are $A_{i}$ and $A_{i+1}$, respectively. Altogether, half of aggregate income of $L$ is spent on one or both of these goods. If consumption of both of these goods occurs at some moment in time, then maximization of (5) implies that the quantities purchased of each one must satisfy

$$
\frac{C_{i}}{A_{\mathrm{i}}}=\frac{1}{1+\lambda}\left(\frac{1}{A_{\mathrm{i}+1}}-\frac{\lambda}{A_{\mathrm{i}}}+\frac{L}{2}\right)
$$

and

$$
\frac{C_{i+1}}{A_{i+1}}=\frac{1}{1+\lambda}\left(\frac{\lambda}{A_{i}}-\frac{1}{A_{i+1}}+\frac{\lambda L}{2}\right) .
$$

When the expression in (7) or (8) gives a negative value for consumption of one good or the other, then in fact none of that good is consumed and spending of $L / 2$ falls entirely on the other product.

We can define $Q_{b}$ as the level of cumulative experience in producing good $i$ at the moment when good $i+1$ is first introduced, and $Q_{h}$ as the cumulative experience in producing good $i+1$ when production of good $i$ ceases. ${ }^{16}$ It is easy to show

\footnotetext{
${ }^{16}$ The first of these is found by substituting for $A_{i}$ in terms of $Q_{i}$, using $Q_{i-1}=\bar{A}-A_{0}$ and $A_{i+1}=A_{0}$ and solving (8) for the value of $Q_{i}$ that makes $C_{i+1}=0$. The second is found by

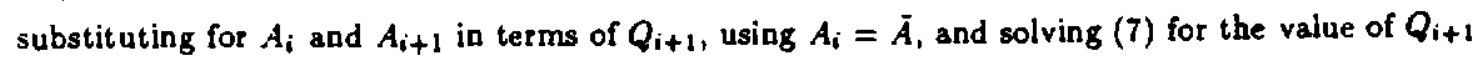
that makes $C_{i}=0$.
} 
that parameter values exist for which $Q_{h}<Q_{b}$ (so that the replacement of each generation by the next takes place smoothly) and also $Q_{b}<\bar{A}-A_{0}$ (so that each product exhausts its learning potential before it exits the market).

What are the effects of trade when consumers have the alternative preferences? They are the same as before. A country that begins with a technological lead will widen its lead over time, and eventually (if not immediately) take over the world's production in the sector with learning. The other country will find that trade slows its productivity growth, perhaps only moderately at first, but to zero in the long run. The initially lagging country might gain from trade, because it can import the leading country's advanced goods, but gains from trade are in no way ensured.

\subsection{Technological Leapfrogging}

Up to this point we have dealt with situations in which national learning by doing means that an initial technological lead is self-reinforcing (see, however, the last footnote). Brezis et al. (1993) identify circumstances under which leapfrogging may occur; that is, a country that begins technologically behind may eventually surpass its trade partner, only to be overtaken again in a subsequent phase of the periodic steady state. This happens because new and superior technologies, which arrive exogenously in their model, may be adopted by the lagging country even though they are not profitable in the leading country.

To see how this works, let preferences be given by (4) and consider a closed economy. At first, only goods with indexes up to and including $j$ can be produced, with one unit of labor yielding one unit of the numeraire or $A_{i}$ units of good $i$, where $A_{i}=A_{0}+\min \left(Q_{i}, \bar{A}-A_{0}\right)$ for $i \leq j$. Here, all spillovers are confined to the industry in which they are generated and the opportunities for learning by doing are bounded for every product. We assume that the knowledge stock for good $j$ (and perhaps for all goods before it) has already reached its maximum of $\bar{A}$ at time 0 .

Now let the technology for good $j+1$ suddenly become available, although of course no producer has had any experience in using it. The technologies for producing goods $j+2, j+3$, and so on, will arrive subsequently, at regular (but perhaps long) intervals 
of time. At the moment when it first becomes feasible to produce good $j+1$, the price of this good is $1 / A_{0}$, while that of good $j$ is $1 / \bar{A}$. Consumers buy the new good only if $\lambda>\bar{A} / A_{0}$. Otherwise, the new and superior product never is introduced into the market, and productivity growth does not pick up until some even more desirable product arrives on the scene.

But now let there be two countries and trade. At the outset, the home country produces good $j$ with labor productivity $1 / \bar{A}$, while the foreign country has no experience in this industry. Then, if the countries are not too different in size, the foreign country initially specializes in producing the numeraire good while the home country produces only good $j$. With this pattern of specialization, the foreign wage equals one and equality of foreign labor income and spending on the numeraire good implies that $w=\mu L /(1-\mu) L^{*}$. The hypothesized pattern of specialization is realized for $\bar{A} / A_{0}>\mu L /(1-\mu) L^{*}>1$.

What happens when the technology for producing good $j+1$ comes along? If the new generation of good is sufficiently better than the current generation $\left(\lambda>\bar{A} / A_{0}\right)$, then producing with the new technology would be profitable in either country. The model does not tell us which country would adopt it first, but as soon as one gains a small edge in experience the pattern of trade gets locked in. A more interesting equilibrium can arise if the superiority of the new generation is not so large $(\lambda<$ $\left.\bar{A} / A_{0}\right)$. Then producers in the home country, who must pay $w$ to their labor no matter which technology they use, will be unable to produce good $j+1$ at a profit in competition with good $j$. On the other hand, production with the new technology may be profitable in the foreign country. There, the wage rate initially equals one, so the new good can be offered at a competitive price of $1 / A_{0}$. Consumers will have positive demand for the good at this price provided that $\bar{A} / A_{0}<w \lambda=\lambda \mu L^{*} /(1-\mu) L$. In the event, the new technology will be adopted by the foreign (lagging) country. As soon as this happens, the wage rate in the home country falls, so that the quality adjusted price of its knowledge-intensive good of generation $j, w \lambda / \bar{A}$, matches that of the foreign country's good of generation $j+1$. With $w=\bar{A} / \lambda A_{0}>1$, the home country still specializes in the production of good $z$ while the foreign country produces 
the numeraire good and good $j+1 .{ }^{17}$

Over time, the foreign country gains experience at producing good $j+1$. As it does so, its productivity rises and the price of its product falls. Demand for good $j$ produced by the home country declines. The home wage must fall, so that consumers are still willing to buy this good. Eventually, the home wage falls to $w=1$. In the next instant, the home country takes over production of the numeraire good, and the foreign county specializes in the production of good $j+1$. From then on, $w^{*}$ rises, until learning by doing in the $j+1^{\text {st }}$ ends when $A_{j+1}=\bar{A}$. Finally the world economy enters a stationary period which persists until the technology for good $j+2$ arrives, whereupon it is adopted in the home country. The countries alternate the lead position in the knowledge-intensive sector indefinitely.

Essentially the same pattern emerges if preferences are given by (5), except that the location of production of the numeraire good switches only gradually, rather than abruptly, from country to country. (We leave this case as an exercise for the interested reader.) Indeed, leapfrogging can arise anytime learning by doing is bounded for a given product and specific to the product and country. Then, if the eventual superiority of a new technology is not enormous, existing producers will pass over that technology in favor of the one in which they are already experienced. No single firm in the experienced country will find it profitable to change, in view of its inability to internalize the externalities from learning. But firms in the lagging country may be able to adopt the new technology, even though they lack experience in using it, because they initially face a lower wage. When they do so, their productivity improves over time and eventually the superiority of the new technology spells the demise of the old. In short, the lagging country, by dint of its lack of experience with the existing technology, always enjoys a comparative advantage in any new one that may happen along.

\footnotetext{
${ }^{17}$ The foreign country's output of good $j+l$ at the moment of its introduction to the market is the solution to the equation $\mu\left(L^{\bullet}+w L\right)=\bar{A} L / \lambda \bar{A}+Z_{j+1} / A_{0}$. The left-band side of this equation is total spending on non-numeraire goods, while the right-band side gives the value of output of goods $j$ and $j+1$ at the market-clearing prices.
} 
This concludes our discussion of learning that occurs as an accidental by-product of manufacturing activities. We have seen that the traditional forces of comparative advantage dominate long-run outcomes whenever knowledge spillovers are global in scope. In contrast, when knowledge spillovers are confined to a single country or region, the vagaries of history can influence the trade patterns even in the long run. National spillovers introduce a positive feedback that tends to reinforce any existing pattern of specialization and trade.

\section{Innovation}

Accidental discoveries undoubtedly play an important role in the advance of technology. But firms also invest vast resources in order to generate productivity improvements; in the advanced industrial economies, private spending on research and development typically exceeds two percent of industrial value added, and this number has been growing steadily in recent years. In this section we discuss the relationship between trade and technological progress when new technologies are the result of intentional investments.

Deliberate investments in knowledge require an environment where intellectual property rights are protected. Without such protection, investors cannot appropriate the fruits of their labor. In some cases, the legal system provides the needed protection, as when governments grant patents for original ideas. In other cases the protection comes more or less automatically, because imitation is costly and trade secrets can be preserved. A patent or trade secret typically gives an innovator the ability to exercise monopoly power in the product market. That is, a firm with proprietary access to an innovative technology usually can price above'marginal cost without losing all of its sales. And the more unique and superior the innovator's technology, the greater will be the monopoly power and the larger the reward (see Arrow (1962)]. This explains why imperfect competition features prominently in the various models we shall discuss below. 


\subsection{Economies due to Increasing Specialization}

It is useful to begin our discussion of endogenous innovation with a model that has many parallels with our treatment of learning by doing. The model is one where productivity gains stem from increasing specialization of the production process. The particular formalization is due to Ethier (1982a).

Consider an industry in which output is manufactured from an assortment of intermediate inputs, with a greater number of inputs associated with more specialization and refinement of each stage of production. In this setting, it is reasonable to suppose that total factor productivity will vary with the degree of specialization. A CES production function can be used to capture this idea. We suppose

$$
X=\left[\int_{0}^{n} z(j)^{\alpha} d j\right]^{1 / \alpha}, 0<\alpha<1,
$$

where $X$ denotes final industry output, $z(j)$ represents the input of intermediate good $j$, and $n$ is the number of intermediates employed. We treat $n$ as a continuous variable for convenience.

Given the number of intermediates in use, the technology represented by (9) exhibits constant returns to scale. We assume that each producer takes the set of available intermediates as given. Since each has an incentive to use some of every available input (that is, to specialize the production process as finely as possible), the number of intermediates in use is effectively beyond its control. Thus each producer of final goods perceives constant returns in production. The producers behave competitively, pricing their output equal to perceived marginal cost.

Now suppose that every intermediate input is used in equal quantity $z$, as will be the case when the intermediates carry the same price. Then $X=A(\cdot) Z$, where $Z=n z$ is the aggregate quantity of intermediates and $A=n^{(1-\alpha) / \alpha}$ is an index of the state of technology. ${ }^{18}$ This reduced-form production function has the same form as (2), which we used to study learning by doing. The difference, however, is

\footnotetext{
${ }^{18}$ Whenever all intermediates are produced with the same constant returns to scale production function, it is meaningful to define an aggregate measure $Z$, where $Z$ too can be produced with constant returns to scale.
} 
that whereas the index of the state of technology in (2) measured the accumulated experience in manufacturing the final good, here it depends upon the number of available intermediate inputs. This number will reflect cumulative investment in $R \& D$, if intermediates must be invented before they can be produced.

We proceed to determine the flow of profits that accrue to a new invention. Inventors are granted indefinite patents and produce their differentiated input with one unit of labor per unit of output. With the number of intermediate inputs given at a moment in time, each patent holder faces a demand with an elasticity approximately equal to $1 /(1-\alpha) \cdot{ }^{19}$ The firm equates marginal cost with marginal revenue, which calls for a mark-up pricing rule,

$$
p_{x}=\frac{1}{\alpha} w .
$$

This yields an equilibrium profit flow of

$$
\pi=(1-\alpha) \frac{p_{z} Z}{n}
$$

Here, profits per variety are inversely proportional to the number of competitors and directly proportional to aggregate spending on intermediates. Aggregate spending matches the value of final output, because producers of final goods earn zero profits. ${ }^{20}$

The incentive to innovate is given by the present value of the profit stream. If $Z$ is constant, $n$ grows at a constant rate $g$, and the prices of intermediates grow at a common, constant rate, then the present value of profits from any time $t$ onward equals $\pi(t) /(r+g)$, where $r$ is the real interest rate in terms of intermediates. It follows that the incentive to innovate varies directly with the extent of product differentiation (as reflected in the parameter $1 / \alpha$ ) and inversely with the number of available intermediates, the rate of introduction of new intermediates, and the real rate of interest.

\footnotetext{
${ }^{19}$ The approximation neglects terms of order $1 / n$; it becomes precise as the number of competing differentiated products grows large. For further details, see Helpman and Krugman (1985, p.118-119) or Dixit and Stiglitz (1993).

${ }^{20}$ Equations (10) and (11) apply at each moment in time. We omit the time variables in order to simplify the notation.
} 
Having derived a measure of the incentive to innovate, we need to introduce a cost of innovation and examine how private benefits and costs interact to determine the evolution of industry output. The simplest way to treat the innovation cost is to assume that there exists a deterministic production function relating $R \& D$ inputs, which we take to include labor and a stock of knowledge capital, to research output, which includes a flow of blueprints and perhaps additions to the knowledge stock. We assume that there are constant returns to labor in research, so that $\dot{n}=A_{l}\left(K_{n}\right) L_{l}$, where $\dot{n}$ is the flow of newly invented products, $L_{l}$ is the labor employed in R\&D, and $A_{l}(\cdot)$ measures the productivity of labor in the research lab. Research productivity varies with the stock of knowledge capital $K_{n}$, which represents the accumulated scientific and engineering wisdom in society. We treat general knowledge as a free public good. Then the cost of inventing a new product is $w / A_{l}\left(K_{n}\right)$.

With free entry into $R \& D$ and an active research sector, the value of a blueprint matches the cost of inventing a new product. Using the present discounted value of profits for the value of a blueprint, we have (after rearranging terms)

$$
\frac{(1-\alpha) Z}{\alpha n} A_{l}\left(K_{n}\right)=r+g \text {. }
$$

The left-hand side of (12) gives the profit rate for a firm producing a differentiated product (i.e., the ratio of profits to the value of the blueprint) while the right-hand side gives the real effective cost of capital. The latter includes not only the interest cost, but also the rate at which the blueprint value depreciates in view of the ongoing entry of new competitors.

Equation (12) has important implications for the long-run dynamics of an economy with costly innovation and free entry into R\&D. Suppose that the stock of knowledge ceases to grow, or that its contribution to research productivity peters out. Then, if $n$ grows continually, the profit rate on the left-hand side of (12) must eventually fall below the effective cost of capital. At this point, there is insufficient incentive for conducting research [see Judd (1985)]. Evidently, ongoing innovation requires sustained increases in research productivity. The analogy with our earlier discussion of bounded learning by doing is clear: If opportunities for learning are bounded or 
the learning process runs into diminishing returns, then the engine of technological progress must eventually grind to a halt.

Although the formal structure of our model is similar to that for learning by doing, the underlying economics may be different. Whereas bounded learning by doing in manufacturing seems a plausible and even compelling assumption, it is easy to imagine that knowledge useful for conducting research might continue to accumulate forever. In industrial research, almost every new invention builds on some that came before it and many industrial research projects generate knowledge beyond what was intended for the specific application. If creative ideas are in limitless supply, so too may be the opportunities to improve upon research productivity.

Let us suppose, then, that an unbounded potential exists for learning about how better to invent new products. We assume that each research project generates some additional knowledge that is potentially useful to subsequent inventors and that this knowledge enters rapidly into the public domain. In particular, we take $K_{n}$ to be proportional to the number of research projects previously undertaken (so there are no diminishing returns to learning) and $A_{I}$ to be proportional to $K_{n}$; then we can write $A_{I}\left(K_{n}\right)=n / a_{l}$. In the event, the profit rate does not decline with an increase in the number of available products, because as the expansion of variety reduces the profitability of a new product, the expansion of knowledge reduces the cost of inventing it as well.

It is possible now to have ongoing innovation in the steady state. The long-run rate of innovation satisfies

$$
\frac{(1-\alpha) Z}{\alpha a_{l}}=r+g
$$

To close the model, we must specify how the equilibrium output of intermediate goods and the real rate of interest are determined. Take for the moment the case where the industry under examination comprises the entirety of the domestic economy. Then all labor must be employed either in manufacturing intermediate goods or in conducting industrial research. (Recall that final goods are produced from intermediates alone.) Total employment in manufacturing matches the aggregate output of intermediates, 
while employment in $R \& D$ is $a_{l} / n$ times the number of new products invented per unit of time. Thus, equilibrium in the labor market requires

$$
a_{I} g+Z=L
$$

were $L$ once again represents the aggregate labor force. Finally, suppose that households maximize the discounted value of the $\log$ of consumption and that they can borrow and lend on a frictionless credit market. Then the real interest rate in terms of intermediates will be constant and equal to the subjective discount rate $\rho .{ }^{21}$

It is now straightforward to solve for the long-run rate of innovation in a closed economy of the type just described. Combining (13) and (14), we have $g=(1-$ $\alpha) L / a_{I}-\alpha \rho$. The innovation rate is larger the less substitutable are the specialized inputs, the greater is the stock of resources suitable for conducting $R \& D$, the more productive are these resources in the research lab, and the lower is the subjective discount rate. Moreover, the "long run" is achieved immediately, with a constant rate of innovation $g$ at every moment in time [see Grossman and Helpman (1991a, ch.3)].

We now have the building blocks needed to examine how trade evolves in a world economy with endogenous technological progress. The answer, it turns out, depends upon the nature of the stock of general knowledge capital. We will distinguish two case, one where knowledge spillovers are local in scope, so that only national R\&D contributes knowledge that is useful in subsequent research, and another where the spillovers are global in scope, so that knowledge generated in any country augments research productivity worldwide. ${ }^{22}$ This distinction is reminiscent of the one we made in our earlier discussion of learning by doing, and many of the implications of it will

\footnotetext{
${ }^{21}$ When households maximize $\int_{t}^{\infty} e^{-p s} \log [c(s)] d s$ subject to an intertemporal bidget constraint, the first-order condition implies $\dot{c} / c+\dot{p}_{x} / p_{x}=r+\dot{p}_{x} / p_{3}-p$, where $p_{x}$ is the price of final output. In every momentary equilibrium we must have $c=X$ and $p_{x} X=p_{3} Z$. Then, since $Z$ is constant in

the steady state, the real interest rate in terms of intermediates, $r$, is equal to $p$.
${ }^{22}$ Grossman and Helpman (1990a) describe an intermediate cage nates globally, but international transmission involves Some such intermediate case is probas Eaton and Kortum (1994), and Bernstein and Mohnen (1994) present evidence of the existence
} 
be the same. There are two new points to emphasize, however. First, whereas trade had no direct effect on productivity in the model of learning by doing, here access to foreign-made intermediate goods raises productivity in manufacturing even in the absence of international knowledge spillovers. Productivity in manufacturing depends on the range of intermediates used in production, irrespective of the sources of those various inputs. Second, it may well be that foreign trade itself influences the degree to which knowledge spills across international borders. Knowledge may be transmitted, for example, when exporters describe the best uses of their products or when importers report the needs of their customers. The role of trade as a conduit for knowledge has been explored in Grossman and Helpman (1991c).

\subsection{International Knowledge Stocks}

We begin with the case where knowledge spillovers are global in scope. For simplicity we assume that dissemination is immediate, so that researchers worldwide draw on a common stock of general knowledge. Denoting this public input again by $K_{n}$, we suppose that $K_{n}$ is proportional to the cumulative number of research projects previously undertaken in all countries combined. We also assume that countries have the same production technologies, with one unit of labor required per unit of intermediate and $a_{I} / K_{n}$ units of labor required for each invention.

Now consider a world economy that produces only the single final good, $X$. In the steady state, each country produces and exports a constant fraction of the total number of input varieties. This fraction matches the country's share in the world supply of labor. All countries import the differentiated varieties invented and produced abroad and all experience the same rate of productivity growth in their final-goods sectors. Productivity growth in final manufacturing is proportional to the rate of expansion of international spillovers from R\&D activity, while Jaffe et al. (1993) provide evidence that the extent of knowledge spillovers from R\&D falls (at least for some time) with geographic distance from the source. Lichtenberg (1992) explicitly rejects the hypothesis of complete and instantaneous international R\&D spillovers, while Eaton and Kortum (1994) find that technology diffusion is consider ably more rapid within than between countries. Still, the extreme cases that we consider are pedagogically useful for bringing out the forces at work. 
in the total number of input varieties, with a factor of proportionality of $(1-\alpha) / \alpha$. In each country, and in the world as a whole, the number of produced inputs expands in the long run at the rate $g=(1-\alpha) \sum_{j} L^{j} / a_{I}-\alpha \rho$, which is larger than the rate of innovation experienced by any country in autarky. So integration boosts not only manufacturing productivity at a moment in time (by expanding the range of intermediate inputs available to a producer of final goods) but also the long-run rate of productivity growth (by providing access to the general knowledge generated abroad). There are both (welfare) gains from trade and a positive effect of trade on the rate of technological progress in every country.

While the above model highlights the importance of trade in differentiated inputs, it allows limited scope for interindustry trade. Besides trading intermediates, a country may import some final goods. But inasmuch as the assembly of final goods requires no primary resources here, such trade has no meaningful effects. To consider the determinants of the pattern of trade, we must further elaborate the general equilibrium structure of our model. To this end, suppose that two primary factors-say, unskilled labor and human capital-are used in manufacturing the various inputs in to the production of final good $X$. Suppose also that there is a second final good $Y$ that is produced directly with these same primary inputs, also with constant returns to scale but with no prospect for technological progress. Finally, suppose that human capital and unskilled labor are also used in $R \& D$ and that the three activities employing the primary resources vary in their factor-intensity requirements. How will the pattern of trade evolve over time?

In the short run (i.e., shortly after trade begins), history may afford some particular country an initial advantage in producing intermediates. That is, a country may have invented a disproportionate number of intermediates before trade commenced, in which case it would become an immediate net exporter of these goods. But any competitive advantages due to prior experience are bound to be short lived; initial conditions play no role in determining the ultimate pattern of trade when general knowledge is a global public good [see Grossman and Helpman (1991a, ch.7)].

Suppose there are two countries, $A$ and $B$. Figure 3 portrays the long-run equilib- 
rium when intermediate goods must be produced where they are invented and when consumers allocate a constant fraction of their spending to the technology-intensive good $X$. The dimensions of the box represent the world endowment of the two factors of production. The origin for country $A$ is at the lower left corner, and the vector $O^{A} E$ represents its factor endowment. That of country $B$ is represented by $E O^{B}$, which culminates in its origin at the upper right corner. The figure depicts the case where country $A$ has the relatively larger endowment of human capital compared to its endowment of unskilled labor.

We use the familiar procedure of constructing a long-run trade equilibrium by showing that it is possible to allocate resources in each country so as to mimic the steady-state outputs of a hypothetical integrated equilibrium with no international borders. Assume that, in the integrated equilibrium, the vector $O^{A} R$ of resources would be used in inventing new intermediate inputs, the vector $R X$ would be used in manufacturing the existing assortment of these goods, and the vector $X O^{B}$ would be used in producing the traditional good $Y$. Clearly, the figure depicts the case where $\mathrm{R} \& \mathrm{D}$ is the most human-capital-intensive activity and the production of the final good $Y$ is the least so. In the long-run equilibrium with trade, country $A$ can employ the vector $O^{A} R^{A}$ in its $R \& D$ labs, the vector $R^{A} X^{A}$ in manufacturing the varieties of intermediates that it has previously developed, and the vector $X^{A} E$ in the traditional manufacturing sector. Country $B$ can employ the resources $E R^{B}$ in R\&D, $R^{B} X^{B}$ in producing intermediates, and $X^{B} O^{B}$ in producing good $Y$. The important thing to notice is that the ratio of $O^{A} R^{A}$ to $R^{A} X^{A}$ is the same as the ratio of $E R^{B}$ to $R^{B} X^{B}$, which is the same as the ratio of $O^{A} R$ to $R X$; in other words, the ratio in country $A$ of the size of its research sector to the size of its sector manufacturing intermediates is the same as for country $B$, which in turn is the same as for the world as a whole. This means that, when equal quantities of each intermediate are produced, the number of different intermediates produced in each country is in exact proportion to the number of intermediates being invented there per unit time. The lat ter condition is a requirement of a steady-state equilibrium in which intermediates must be produced where they are invented and the allocation of resources among 
sectors in each country is constant over time. ${ }^{23}$

In the long-run equilibrium depicted by the figure, aggregate outputs of intermediate goods are constant in each country, as are outputs of the traditional good $Y$. So too are the fractions of the total number of intermediate goods emanating from each country, which implies that the rate of innovation $g$ is eventually the same in both places. Now suppose for concreteness that assembly of good $X$ from intermediates takes place where the good is consumed, as it would for example if $X$ were nontradable (or if the intermediates were in fact final goods and $X$ were only a fictitious good representing a subutility index). Then intraindustry trade in intermediates would coexist with a predictable long-run pattern of interindustry trade. In particular, the country with an abundance of the factor used intensively in the high-technology sector (that is, in research and production of intermediates together) becomes a net exporter of intermediate goods. The other country balances its long-run deficit in the high-technology sector by exporting the unskilled-labor-intensive, traditional good. ${ }^{24}$

We find that factor abundance alone determines the steady-state pattern of intersectoral trade. This is like the result for static trade models with monopolistic competition, except that here it applies only as a long-run proposition. A humancapital rich country may begin as a net importer of intermediates, if historically it has not been very active in inventing new products. But once it becomes integrated into the world economy, its natural comparative advantage will eventually take hold. The country will specialize disproportionately in the R\&D activity, and over time will develop the capacity to produce a disproportionate share of the differentiated

\footnotetext{
${ }^{23}$ Figure 3 is constructed under the assumption that the relative factor endownts in the two countries do not differ too greatly (i.e., point $E$ lies inside the parallelogram $O^{A} X O^{B} X^{\prime}$ ), which enables a long-run equlibrium with factor price equalization. For endowments outside the parallelogram, long-run factor prices must differ and at least one of the countries must specialize in production.

${ }^{24}$ Out discussion presumes that no country imports in both sectors (on net) in the steady state. It is in fact possible in our model that a country might run a long-run trade surplus in order to service debt acquired along the equilibrium path. If the overall deficit were large enough, and its factor composition not too different from that ahroad, the country could even have a net surplus in both sectors.
} 
products.

What is the effect of trade on a country's technological progress in this setting? Consider first the case where factor compositions are everywhere the same (i.e., the point $E$ in Figure 3 lies on the diagonal of the box). In this case, trade accelerates every country's long-run rate of innovation, just as it does when there is only one final good and one primary factor. When relative factor endowments are the same, so too are long-run factor rewards and the long-run division of resources among sectors. Then countries do not engage in interindustry trade in the long run, although they do trade their unique varieties of the intermediate goods. With knowledge spillovers that are global in reach, the knowledge stock grows faster in a larger world economy than any single, smaller economy with similarly allocated resources. It follows that the pace of innovation must increase as a result of the scale economies associated with producing knowledge [see Rivera-Batiz and Romer (1991)].

Now consider a world where countries differ in their factor composition. Continuity implies that innovation must accelerate if the differences in factor abundance are small. But what if these differences are larger, though still not so large as to eliminate the possibility of a long-run equilibrium with factor price equalization? With factor price equalization, trade is like an enlargement of the economy. The human-capitalpoor country finds itself a part of a larger world economy that is relatively better endowed with human capital. Since an increase in the endowment of human capital causes an expansion of the relative size of the world research sector, this country experiences an increased rate of innovation in its high-technology sector. ${ }^{25}$

The conclusion differs for the human-capital-rich country. On the one hand, this country too enjoys the benefits of a larger world economy. On the other hand, its relative endowment of human capital in autarky exceeds the human-capital-to-labor ratio for the integrated world economy. Depending on the elasticities of substitution between human capital and unskilled labor in the three activities, the overall size of

\footnotetext{
${ }^{25}$ Note, however, that trade causes this country to specialize relatively. more than in autarky in the production of traditional goods. So while trade must increase the country's rate of technological progress in industry $X$, it may slow its average rate of technological progress, when sectoral productivity gains are weighted by initial or final GDP shares.
} 
the world R\&D sector may be larger or smaller than the size of its own sector in autarky [see Grossman and Helpman (1991a, ch.9)]. If these elasticities are small, then the human-capital-rich country may see its rate of innovation slowed as the (long-run) result of an opening of trade and knowledge flows.

\subsection{National Knowledge Stocks}

We saw in our discussion of learning by doing that new factors enter into the determination of the trade pattern when knowledge spillovers are local rather than global in reach. Global learning means shared experience and so only the traditional forces of comparative advantage can shape the pattern of international trade. But local learning means distinct national experience, which introduces a role for history in determining the trade pattern. We will see that a similar conclusion is warranted when technology results from deliberate investment. In this case, global knowledge means similar research capability and so traditional forces determine whether a country is competitive in the research lab. Then a country that has an appropriate resource base can overcome any initial disadvantage in the knowledge-intensive sector by specializing relatively in R\&D. But initial disadvantages may have long-lasting effects if a lack of local research experience means low research productivity.

A simple model helps to reveal the novel features of a world economy with local knowledge capital. Let there again be two countries, $A$ and $B$, and a single primary factor of production. As before, a traditional consumer good is manufactured with constant returns to scale. Also, a high-technology product is assembled from differentiated inputs and research generates the blueprints for intermediates. But now suppose the knowledge capital that determines national research productivity accumulates in proportion to local $R \& D$ activity. It takes $1 / K_{n}^{j}$ units of labor to invent a new intermediate in country $j$. Finally, with knowledge capital proportional to cumulative R\&D experience, we choose units so that $K_{n}^{j}=n^{j}$.

Suppose first that the countries are of equal size $\left(L^{A}=L^{B}\right)$ and also that $\left(1-b_{x}\right) / b_{x} \geq L^{j} /\left(L^{j}+\rho\right)$, where $b_{x}$ is the fraction of spending devoted to good $X$ and $\rho$ is the subjective discount rate (equal to the long-run real interest rate). The 
inequality guarantees that both countries must produce some traditional output in order to satisfy world demand for good $Y$. If both countries do (always) produce the traditional good in common, then competitive pricing ensures that their wage rates will be equalized all along the equilibrium path.

Now consider the incentive that exists in each country to engage in R\&D. With wage rates always the same, the prices of intermediates produced in both countries are the same. So the instantaneous profits earned by a producer of an intermediate good are the same. And the value of a blueprint, which equals the present value of the profit flow, is also the same, assuming that the real interest rate is the same (as it will be if international borrowing and lending takes place). This means that the R\&D activity will be more profitable in the country that has the lower cost of innovation. But the cost of an invention in country $j$ equals $w a_{I} / K_{n}^{j}$, and $w$ and $a_{I}$ are common to the two countries. It follows that $R \& D$ is more profitable in whichever country happens to have the larger knowledge stock; i.e., in the country that has the greater prior experience in $R \& D$.

Suppose it is country $A$ that begins with more research experience. Then initially this country's researchers have a competitive advantage in the research lab, and they perform all of the world's $R \& D$ at time 0 . But then additional knowledge accumulates in country $A$, while in the absence of international knowledge spillovers, the knowledge stock remains unchanged in country $B$. Country $A^{\prime}$ s competitive lead in $R \& D$ widens and there is even greater reason for this country to conduct all of the world's research in the next period. In other words, the initial lead is self-reinforcing. Eventually country $A$ will come to dominate production in the high-technology sector [see Grossman and Helpman (1991a, ch.8) for further details].

This example illustrates several points. First, an accident of history can have long-lasting implications for trade when there is a national component to the knowledge capital stock. In the example, the two countries are identical except for their initial conditions, and yet there is the clear prediction that the initial technological leader must come to dominate the world market in high-technology goods. ${ }^{26}$ Second,

${ }^{26}$ Markusen (1991) derives a similar result in a two-period model. 
trade can reduce the rate of innovation and growth in a country that begins with a technological disadvantage. Here, the initially lagging country would continue to innovate (indeed, at the same pace as the leader) if it were isolated from competition with its more advanced trade partner. Yet, as soon as it opens itself to trade, competitive forces drive its resources out of the R\&D activity. But third, the rate of innovation (or even the growth rate of national output) can be a misleading gauge of aggregate welfare. In our example, residents of both countries experience the same wage trajectory and have access to the same investment opportunities. With free international trade, they can buy the same goods at the same prices. It follows that a unit of labor enjoys the same lifetime utility regardless of where the worker happens to reside. Not only do residents of both countries enjoy the same welfare levels in this example, but both gain from trade, even though all innovation happens to take place in only one of the countries.

While our example is one where an initial technological disadvantage has no adverse welfare consequences, this need not always be the case. Consider, for instance, what happens when one country starts with greater knowledge and $\left(1-b_{x}\right) / b_{x}<$ $L^{j} /\left(L^{j}+\rho\right)$. Then it may be that both countries conduct $R \& D$ for a while, but again the initial leader will widen its knowledge advantage over time and eventually come to dominate the world market for the differentiated inputs [see Grossman and Helpman (1991 a, ch.8)]. Moreover, the demand for the high-technology product is sufficiently great under this parameter restriction that the country producing the preponderance of intermediates comes to enjoy a higher wage than its trade partner. In this case an initial national advantage in research productivity translates into a higher national standard of living. Indeed, the country that begins as the technological laggard might even suffer from trade as compared to its welfare along the autarky equilibrium path. ${ }^{27}$

In both of the cases just described, a country that initially lags behind in the

${ }^{27}$ The possibility of losses from trade arises because the autarky equilibrium is distorted (no compensation for the spillovers to the general knowledge stock) and the effect of trade on the initial lagging country is to exacerbate the distortion. The situation is similar to that with national increasing returns to scale, where a country that specializes in the constant-returns sector may lose from trade. See Ethier (1982b) and Helpman (1984a). 
technology race can never catch up. While prior experience generally does provide an edge to a country in a world of national knowledge stocks, the prospects for latecomers are not always so bleak. For one thing, a natural comparative advantage in R\&D-arising, for example, from an abundance of human capital-can give an inexperienced country a cost advantage that may offset its disadvantage due to a lack of accumulated knowledge. Even if a country does not have any natural comparative advantage in conducting $R \& D$, it may be able to overcome an initial lack of research experience if it happens to be a large country. The benefit of size when there are national knowledge stocks is similar to the one that arises when there are national increasing returns to scale in production [Helpman, (1984a)] or national knowledge associated with learning by doing. It arises because $R \& D$, as we have conceived of it, is an activity with dynamic increasing returns to scale.

To see tbis point, consider further the case where there is a single factor of production and identical input coefficients in manufacturing in the two countries. Again assume that one of the countries has an initially larger national knowledge base. For the lagging country to be competitive in $R \& D$, its wage rate would have to be lower than that in the leading country. But with a lower wage, its cost of producing traditional manufactures would also be lower, and so its firms would capture all of the world's market for this competitively-priced good. The satisfaction of world demand for traditional goods would absorb a portion of its labor supply, leaving only a residual supply for inventing and producing intermediate goods. Still, if the country were large enough, that residual might be bigger than the entirety of the labor force of its trade partner. In the event, the initial laggard could conduct more research activity than its smaller rival and thereby overcome its knowledge deficiency.

Our examples show that initial conditions and, indirectly, country size influence the long-run pattern of trade when spillovers from research activity are confined to within a nation's borders. What about the effects of trade on technological progress under these conditions? We have seen already that trade may slow a country's rate of innovation, if the country bas an initial disadvantage in research productivity and if there is another production sector into which its resources might be driven. Feenstra 
(1990) shows that country size, too, can intervene in the relationship between trade and technological progress. Suppose there is only one final-goods sector in each country, which uses intermediates invented in the research lab. Now all of a country's labor must be used either in developing new technologies or in producing previously invented goods. Innovative firms can sell to a larger market with trade than without. This alone serves to enhance the profitability of R\&D. But global competition means that firms must compete with a larger number of rivals than in autarky. This tends to reduce the incentive for $\mathrm{R} \& \mathrm{D}$. In the small country, where product development is less rapid than in the larger country, profits erode much faster with trade than without. The net effect of trade is to reduce the incentive to innovate and to slow the long-run rate of technological progress. In contrast, the enlarged-market effect dominates for the larger country. Firms there find a greater incentive to innovate in a world with international trade and trade accelerates technological progress all along the equilibrium path, though not in the very longest of runs. ${ }^{28}$

\subsection{Process Innovation and Quality Ladders}

So far, we have equated innovation with the development of new varieties of a horizontally differentiated product. Of course, firms also invest in developing new products that are of higher quality than similar goods available on the market, and in lowering the cost of producing existing goods. Many of our conclusions about the relationship between trade and technological progress apply also to these alternative forms of innovation.

We describe a model with building blocks drawn from Aghion and Howitt (1992) and Segerstrom et al.(1990). ${ }^{29}$ In this model, a final good $X$ again is assembled from intermediate inputs. This time, however, the number of inputs is taken as fixed. Research investments are intended to improve the quality of the various inputs.

\footnotetext{
${ }^{28}$ In the very long run, the large country - with its faster pace of product development-comes to dominate the world economy. Therefore the long-run equilihrium in this country with trade is virtually the same as the long-run equilihrium without trade.

${ }^{29}$ The particular formulation follows Grossman and Helpman (1991h).
} 
Alternatively, these investments can be seen as attempts to reduce their production cost. With either interpretation, a successful innovation reduces the primary resource cost of manufacturing the final good.

To make matters simple, suppose that final production uses a continuum of inputs and that the assembly technology has a symmetric, Cobb-Douglas form. Then we can write

$$
\log X=\int_{0}^{1} \log [\hat{z}(j)] d j
$$

after arbitrarily setting the measure of different inputs to one. Here $\dot{z}(j)$ represents the effective quantity of input $j$, adjusting for the different qualities of the inputs used. $^{30}$ An input that has been improved $m$ times from its initial condition provides $\lambda^{m}$ times as many input services as the basic version of the product, where $\lambda-1>0$ represents the percentage quality increment associated with each improvement.

For every input $j$ there is a state-of-the-art product at every moment in time. The state of the art is the highest quality version of the input whose technology is known. This product, and all earlier vintages, can be produced by their inventors with one unit of labor per unit of output. Assuming that the producers of intermediates engage in Bertrand (price) competition, only state-of-the-art products are sold in equilibrium. These are priced at $p_{z}=\lambda w$, in view of the fact that the competitor with the ability to produce the second highest quality has a marginal production cost of $w$ and a product that is only $1 / \lambda$ times as good.

Since only state-of-the-art inputs are used in equilibrium, the effective quantity of input $j$ is $\lambda^{m(j)} z$, where $m(j)$ is the number of times input $j$ has been improved and $z$ is the common physical amount used of every input. The inputs are employed in equal quantities, because they all carry the same price. Then, (15) implies $X=\lambda^{\bar{m}} Z$, where $\bar{m}=\int_{0}^{1} m(j) d j$ is the number of times that the average intermediate input has been improved, and $Z$ is the volume of intermediates employed in final production. This production function again has the form $X=A(\cdot) Z$, but the technology indicator this time reflects the average number of successful innovations.

\footnotetext{
${ }^{30}$ We use the "quality ladders" interpretation of innovation in the text. Only the wording would need to be changed to describe process innovation.
} 
Now assume that $R \& D$ is a risky investment. A would-be innovator who devotes $\ell$ units of labor to research for a time period of length $d t$ succeeds in developing the next generation of some particular, targeted product with probability $\left(\ell / a_{l}\right) d t$. Let $\vec{\imath}$ denote the average (across intermediates) instantaneous probability of a research success and let $\bar{\ell}$ denote the average employment in R\&D. Then $\bar{m}(t)=\int_{0}^{t} \bar{l}(\tau) d \tau=$ $\left(1 / a_{l}\right) \int_{0}^{t} \bar{\ell}(\tau) d \tau$. In other words, the productivity of the economy once again depends upon the cumulative investment in $\mathrm{R} \& \mathrm{D}$. Also, $d \bar{m} / d t=\bar{\imath}=\bar{\ell} / a_{l}$. So, in a steady state with constant employment in manufacturing and $R \& D$, the rate of innovation and the rate of growth of final output are both proportional to total employment in the research activity. We see that the links between $R \& D$ investment, technological progress, and aggregate growth are quite similar to those in the model of horizontal product differentiation.

Two equations describe the long-run equilibrium for a closed economy that produces only the single, final good. The first equates the cost of $R \& D$ to the expected return. The second ensures full employment of labor, in view of the demands by research labs and manufacturers of state-of-the-art intermediate goods. These two equations have exactly the same form as (13) and (14), which applied to the model of increasing specialization, except that $1 / \lambda$ here takes the place of $\alpha$ there, and $\iota$ here takes the place of $g$ there. Evidently the two models share the same reduced form [see Grossman and Helpman (1991b)].

The model of quality ladders (or process innovation) can be elaborated to address trade issues. Assume, for example, that there are two countries, each capable of generating quality innovations and producing state-of-the-art inputs. Suppose, to begin with, that there is only the single, final consumption good. Then all trade is intraindustry trade. At a moment in time, firms from each country hold the technological lead for some subset of the intermediates, because these firms were the last to succeed in improving the particular products. The technological leaders capture the entire world market and so must export their state-of-the-art products to the trading partner. Notice that the pattern of trade fluctuates over time, as an extant home-country leader for one input will be displaced by a successful innovator abroad, while a home 
innovator will capture the market for a good that was formerly imported. Despite this turbulence at the product level, the aggregates trade flows are stable in the steady state. The equilibrium investment in $R \& D$ in each country is just enough to generate balanced trade at equal wages. In the long run, country $j$ holds the technological lead for a constant fraction $L^{j} / \Sigma_{i} L^{i}$ of the intermediate goods.

How does this trade affect the long-run rate of innovation in each country? The answer is that, just as in the model of horizontal product differentiation with international knowledge stocks, each country enjoys a faster rate of technological progress with trade than without. ${ }^{31}$ Trade stimulates technological progress, because the instantaneous probability of a research breakthrough is greater when two country's would-be inventors are attempting to achieve it than when only one set of researchers is doing so. In other words, the research activity again is characterized by a dynamic scale economy and international trade again enlarges the size of the relevant economy. In the model of horizontal product differentiation, international knowledge spillovers were necessary for world trade to generate a scale economy in research. But here such international spillovers are an inherent feature of the environment. They occur naturally whenever one country succeeds in making the $m^{\text {th }}$ improvement of some input $i$, whereupon researchers there and abroad cease their efforts to make that discovery and begin to pursue instead the $(m+1)^{\text {st }}$ improvement.

If there are instead two final-goods sectors, the determinants of the pattern of interindustry trade also are the same as before. Suppose, for example, that state-ofthe-art inputs are produced with unskilled labor and human capital, and that these factors are also used to conduct $R \& D$ and to produce a traditional, consumption good $Y$. Again, let R\&D be the most human-capital-intensive activity and production of the traditional good, the least so. Then the country that has a relative abundance of human capital will specialize relatively in R\&D. Firms located in this country will win a disproportionate share of the technology races and so come to hold leadership

\footnotetext{
${ }^{31}$ In the trade equilibrium, the average instantaneous probability of a research success in a given industry equals $(1-1 / \lambda) \Sigma_{j} L^{j} / a_{l}-\rho / \lambda$. This exceeds the average success probability in autarky, which is $(1-1 / \lambda) L^{j} / a_{l}-\rho / \lambda$ in country $j$.
} 
positions in a disproportionate share of the intermediate input markets. The humancapital-rich country becomes a net exporter of the technology-intensive intermediates in the steady state, and a net importer of the technologically-unsophisticated, traditional good. As in the previous cases with international knowledge spillovers, the initial conditions have no bearing on the long-run trade pattern [see Grossman and Helpman (199la, ch.7), and Dinopoulos et al.(1993)].

Taylor (1993) gains further insights by relaxing the assumption that all intermediate inputs are symmetric in terms of their prospects for technological advancement, their unit labor requirements, and their contribution to final production. He shows how comparative advantage in innovation interacts with comparative advantage in production to determine the long-run pattern of trade. Only if the ranking of goods by the two count ries' relative labor productivity in manufacturing matches the ranking by their relative labor productivity in innovation does the long-run pattern of trade conform to the simple predictions of the Dornbusch et al.(1977) Ricardian model.

In summary, we have found quite a few analogs between the theory of trade and growth that emerges when technological progress results investments in R\&D and the theory that emerges when such progress is a consequence of learning by doing. In each case, considerations of natural comparative advantage determine the long-run trade pattern if externalities in the learning process spread rapidly around the globe, but size and initial conditions may also be important if the extent of spillovers varies with distance from (or the nationality of) the source. When knowledge spillovers are localized-be they spillovers from learning by doing or spillovers from research discoveries-a small country or one that begins at a technological disadvantage may find that trade slows its technological progress, as competitive forces drive its resources into more traditional, slower-growing activities. Trade may even be harmful for such a country, as it may exacerbate the inefficiencies associated with the existence of externalities and (perhaps) imperfect competition. On the other hand, when the learning process is characterized by dynamic scale economies, the scope for gains from international integration and trade may be many times larger than is suggested by 
static models of trade. It seems that the answers to many of the questions that motivated the recent research hinge on the nature and extent of technological spillovers, about which the empirical evidence is just beginning to accumulate.

\section{Further Topics}

In this closing section we take up three issues that have not been treated elsewhere in this chapter. First we consider how trade and industrial policies affect long-run rates of innovation and national welfare. Next we examine how imperfect protection of intellectual property rights can generate a product cycle in trade between the North and the South. Lastly, we discuss the relationship between endogenous innovation and the incentives for foreign direct investment and the international licensing of technology.

\subsection{Trade and Industrial Policies}

Grossman and Helpman (1991a, ch.6) study the efficacy of trade policies and R\&D subsidies in a small, open, innovating economy. In their model, R\&D gives rise to new varieties of nontraded, differentiated, intermediate goods. ${ }^{32}$ The intermediates are combined with human capital to produce one final good, and with unskilled labor to produce a second, final good. Both final goods are traded at exogenously given world prices. Human capital is needed to perform R\&D while human capital and unskilled labor are used in manufacturing the intermediates. In this setting, consider a tariff that protects the import-competing sector in a country that is relatively abundant in unskilled labor. Protection causes the human-capital-intensive manufacturing sector to expand, which bids up the return to human capital. This raises the cost of innovation and thus reduces R\&D activity in the new, steady-state equilibrium. In contrast, a subsidy to exports of the labor-intensive final good has just the opposite effects. The wage rate rises, the return to human capital falls, and innovation

\footnotetext{
${ }^{32}$ Grossman and Helpman also allow for the case where the intermediates are vertically differentiated and innovation involves quality upgrading.
} 
accelerates, as the $R \& D$ sector absorbs some of the human capital released by the contracting, import-competing sector. Evidently, the effects of trade policy on longrun innovation depend on whether the favored sector is a substitute or complement for $R \& D$ in the general equilibrium production structure.

Trade policies sometimes can provide second-best welfare benefits in economies with endogenous innovation, although policy prescriptions may be far from obvious. For example, a policy that spurs innovation can nonetheless reduce aggregate welfare in the model we have described, if the policy also causes the output of intermediate goods to fall. Similarly, a policy that retards productivity growth can be beneficial, if it promotes greater output of intermediates. The ambiguity reflects the two market distortions that often will be present in an innovating economy. Not only does the market fail to give appropriate incentives for innovation-insofar as private agents generate externalities in the course of creating knowledge--but also there is underproduction of those goods that are sold at prices in excess of their marginal production costs. Ideally, two policy instruments are needed to target these two market distortions.

Rodriguez (1993) and Rodrik (1993) identify another potential use of policy in a small, open economy similar to the one examined by Grossman and Helpman. They assume, contrary to Grossman and Helpman, that the two final-goods industries rely on intermediate inputs to different extents. This modification of the model creates the possibility of multiple equilibria. If the manufacturers of the final good that uses intermediates intensively decide to produce a great volume of output, they will have much derived demand for intermediates. This makes entry into the intermediategoods sector profitable. The resulting economies of specialization raise productivity for the final-goods producers and thus justify their great output. On the other hand, if the producers of the final good that uses intermediates intensively decide to manufacture on a smaller scale, then there is less demand for the inputs and fewer varieties will be developed. In the event, productivity will be lower, and again the producers' decisions will be justified. In such a setting, government policy (including trade policy) often can be used to eliminate the "bad" equilibrium and thereby ensure 
coordination on the Pareto-superior outcome. ${ }^{33}$

In a world of large trading economies, the policies of one country can affect innovative activity in the others. Grossman and Helpman (1991a, ch.10) and Ofer (1991) study the international transmission of policy effects. Both examine world economies with two large countries, with Grossman and Helpman assuming that innovation serves to improve the qualities of a fixed set of goods and Ofer assuming that it expands the variety of differentiated products. In both cases, there are two final goods, one assembled from intermediate inputs and the other from human capital and unskilled labor, and in both cases $R \& D$ is assumed to be the most human-capitalintensive activity, while the production of traditional final goods is assumed to be the least so. In these settings, if one country introduces a small, permanent subsidy to R\&D the steady-state rate of productivity growth will fall in its trade partner. In other words, when a country promotes its research sector, it typically does so at least partly at the expense of innovation abroad. In the quality-ladders model, this occurs because trade in final goods equalizes factor prices, and the $R \& D$ subsidy raises the cost of human capital in both countries. The resulting increase in innovation costs means a decline in the incentive for research in the country where private agents bear the full, unsubsidized cost of R\&D. In the model with horizontal product differentiation, the transmission mechanism is somewhat different. There, the increase in innovation in the subsidizing country raises the real effective cost of capital to firms contemplating research abroad. Both Grossman and Helpman (1991a, ch.10) and Ofer (1991) find that the negative effect on innovation in the trade partner country is never so large as to more than offset the positive effect in the subsidizing country. In each of these cases, a subsidy to $R \& D$ in one country leads to an acceleration of aggregate innovation in the world economy. But in Grossman and Helpman (1990a), where countries are assumed to differ in their productivity in the research lab, a different result is possible. A subsidy to $R \& D$ in the country that has a compara-

\footnotetext{
${ }^{33}$ Murphy et al. (1989), Krugman (1991), and Cicconi and Matsuyama (1993) also study multiple equilibria that can arise when there are increasing returns to scale and imperfect competition. Of these, only Krugman examines an open economy, and he does not explicitly mention the potential use of policy in selecting among equilibria.
} 
tive disadvantage in this activity actually can lead to a decline in the overall rate of productivity growth in the world economy.

Grossman and Helpman (1991a, ch.10) also consider the effects of production subsidies and trade policies. A country that subsidizes production of knowledge-intensive intermediates with the aim of boosting profitability and thereby spurring innovation may be surprised to find that the subsidy actually reduces national and global innovation rates. The direct effect of a subsidy to firms producing intermediates is to raise their demand for primary factors. Not all of these increased demands can be met with resources released from the traditional manufacturing sector, because traditional manufacturing uses relatively little human capital compared to what is needed to produce intermediates. This means that some of the expanded employment of human capital in the intermediate-goods sector must come at the expense of $R \& D$ activity. The reallocation of resources is effected by a rise in the return to human capital, which causes the $R \& D$ labs to release the resources demanded by the subsidized producers.

Trade policies generate more complicated responses. Of course an import tariff or an export subsidy combines a production subsidy with a consumption tax. Consider the effects of uniform protection of the high-technology manufacturing sector; that is, an equal rate tariff on all intermediates purchased from abroad combined with an equal rate subsidy on all foreign sales of domestically-produced intermediates. The production subsidy alone would impede innovation, as we have just noted, but the consumption tax has the opposite effect. It reduces demand for intermediates in the policy-active country and so tends to free resources for use in other activities. Taken together, the effect of the production subsidy and consumption tax on R\&D investment depends on the net trade position of the policy-active country. If the country that protects its intermediate producers is one that exports these high-tech products on net, then the subsidy component of the trade policy is more important, and $R \& D$ activity declines. On the other hand, if the country is a net importer of intermediates, the tax component dominates, and R\&D activity expands. Since the long-run net trade position in high-technology products tends to go hand in hand with 
comparative advantage in $\mathrm{R} \& \mathrm{D}$, protection of the high-technology sector is likely to spur global innovation if and only if the protection is enacted by the country with comparative disadvantage in research. ${ }^{34}$

In leaving this section, we emphasize that our discussion has focused on the response of innovation rates, not aggregate welfare. A complete normative analysis would need to account for the terms-of-trade effects of policy in goods and asset markets, and for the transitional effects of policy in addition to those that persist in the steady state. No such complete analysis has yet been performed for a large, open. innovating, economy.

\subsection{Intellectual Property Rights and North-South Trade}

We have noted that some protection of intellectual property rights is a sine qua non for private investment in new technologies. Yet even where patents and copyrights are strictly enforced, such protection is rarely perfect. There are tremendous incentives for followers to imitate the technological leaders and little prospect that the legal authorities will be able to prevent all forms of reverse engineering and unventing around the patent".

Imitation plays an especially important role in some trade between the North and the South. This is true for several reasons. First, firms in the South have shown only limited ability to develop innovative products of their own. Second, several of the governments of less developed nations have been somewhat lax in their enforcement of foreign intellectual property rights. Finally, the low wage rates of the South make it an especially attractive place for copying some kinds of products, because successful imitators can expect to earn substantial profits in their competition against innovators who bear higher labor costs.

\footnotetext{
${ }^{34}$ The result must be qualified slightly, inasmuch as a country with comparative disadvantage in R\&D may nonetheless become a net exporter of high-technology products in the steady state. This could happen if the country bortowed heavily along the path to the steady state, in which case it would need to run trade surplus in order to service its debt. In the event, the country might run positive trade surpluses in both sectors in the long run.
} 
The pattern of product innovation in the North and imitation in the South gives rise to a product cycle in international trade. We described such trade in Section 1.3, where we reviewed Krugman's (1979) model of exogenous product innovation and technology transfer. Grossman and Helpman (1991a, ch.11) have extended Krug. man's model to incorporate endogenous innovation and imitation based on profitability considerations. They have used the extended model to study how North-South trade affects the long-run rate of technological progress. ${ }^{35}$

Recall that Krugman posited a common CES utility function, $u=\left[\int_{0}^{\infty} c(z)^{\alpha} d z\right]^{1 / \alpha}$, for Northern and Southern households. He assumed that a unit of any good could be produced anywhere with one unit of labor once its technology becomes known. We maintain these assumptions here, but also assume that Northern researchers can increase the stock of known products by $d n$ by devoting $a_{I} / K_{N}$ units of labor to product development for a time $d t$. Here $K_{N}$ is the stock of knowledge in the North, assumed to be equal to the cumulative number of Northern research projects, $n$, by appeal once more to the existence of learning externalities. In the South, a firm can copy $d n_{S}$ products previously developed by the North by devoting $a_{M} / K_{S}$ units of labor to reverse engineering for a time $d t$. The Southern knowledge stock $K_{S}$ might depend on the cumulative Southern experience at imitation or on that experience plus the Northern experience at innovation, depending on whether or not there are international spillovers of knowledge. For simplicity, we suppose here that there are no such spillovers, and specify $K_{S}=n_{S}$, where $n_{S}$ is the number of imitation projects previously completed in the South. Finally, we suppose that a Northern innovator and Southern imitator who share the ability to produce the same differentiated product engage in price competition. This means that only the low cost producer can make positive sales and positive profits in any duopoly equilibrium.

In the North, firms with the unique ability to produce a good that has not yet been copied practice mark-up pricing. They charge the monopoly price $p_{N}=w_{N} / \alpha$, where $w_{N}$ is the Northern wage and also the unit production cost there.. In the South,

\footnotetext{
${ }^{35}$ See also Segerstrom et al.(1990) and Grossman and Helpman (1991a, ch.12), who study models of endogenous quality improvement with imitation in the South.
} 
successful imitators charge either the unconstrained monopoly price, $p_{S}=w_{S} / \alpha$, or the limit price, $p_{S}=w_{N}$, whichever is less. Here we will suppose that the monopoly price prevails. Then, if $x_{i}$ denotes the sales of a frm producing in region $i$, the flow of profits for a typical firm there is $\pi_{i}=(1-\alpha) w_{i} x_{i} / \alpha$. Labor market equilibrium requires $x_{N}=\left(L_{N}-a_{I} g\right) / n_{N}$ and $x_{S}=\left(L_{S}-a_{M} g_{S}\right) / n_{S}$, where $L_{i}$ is the labor supply in region $i, n ;$ is the number of products manufactured there, $g=\dot{n} / n$ is the rate of product innovation and $g_{S}=\dot{n}_{S} / n_{S}$ is the rate of increase in the technological capacity of the South.

The profit flow for a Southern imitator lasts forever. In a steady state in which each country produces a constant fraction of the total number of products, we must have $g_{S}=g$. Then the requirement that the return on investment equals the effective cost of capital in the South implies

$$
\frac{1-\alpha}{\alpha}\left(\frac{L_{S}}{a_{M}}-g\right)=\rho+g
$$

where $\rho$ once again is the subjective discount rate. This equation, describing labor and financial market equilibrium in the South, appears as the horizontal line SS in Figure 4. A Northern firm, on the other hand, faces not only the prospect of a falling patent value due to ongoing innovation, but also the constant risk that a Southern entrepreneur will target its product for imitation and so end its monopoly profit stream. The latter risk raises the effective cost of capital to a Northern firm, so that equality of the rate of return and the effective capital cost implies

$$
\frac{1-\alpha}{\alpha}\left(\frac{L_{N}}{a_{I}}-g\right) \frac{n}{n_{N}}=\rho+g+m
$$

where $m=\dot{n}_{s} / n_{N}$ is the rate of product imitation (fraction of Northern products copied per unit time) and also the instantaneous risk of loss of monopoly power for a Northern producer (assuming, as we do, that Southern imitators choose their targets randomly).

In the long run, the fraction of goods produced in the North approaches the constant $g /(g+m)$. Using this fact and (17), we can plot the equation representing Northern labor and financial market clearing as the upward sloping NN curve in Figure 
4. The intersection of NN and SS at E gives the steady-states rates of innovation and imitation.

From the figure it is immediate that product-cycle trade boosts the long-run rate of product innovation in the North. The autarky innovation rate corresponds to the point where the NN curve hits the vertical axis, because $m=0$ in the absence of Southern imitation. Since the NN curve is upward sloping, E must lie above and to the right of this autarky point. Intuitively, Southern imitation has two distinct effects on the incentive to innovate in the North. First, with imitation, each innovator faces an eventual end to monopoly profits. This most obvious implication of the imperfect protection of intellectual property rights serves to reduce the incentive to innovate by raising the effective cost of capital on the right-hand side of (17). But second, with imitation, some of the products originally invented in the North are later manufactured by the South. This frees up Northern labor to produce more of the remaining products (and also to conduct more $R \& D$ ). As a result, each Northern firm earns greater monopoly profits during its stay in the market, even though that stay is more limited. It turns out that the second effect dominates in the model of horizontal product differentiation with CES utility, and so imperfect protection of intellectual property rights by the South actually serves to encourage technological progress. ${ }^{36}$

The figure can also be used to gauge the effects of region size on steady-state rates of imitation and innovation. An increase in the size of the North causes the NN curve to shift upward, reducing the rate of imitation, but leaving the rate of innovation unchanged. ${ }^{37}$ An increase in the size of the South shifts the SS curve upward, increasing both the long-run rate of innovation and the long-run rate of imitation. It can be shown, moreover, that the relative wage of the North rises

\footnotetext{
${ }^{36}$ This result is not general, however. In a model of Northern quality improvements with Southern imitation of the current state-of-the-art, North-South trade can reduce the long-run rate of technological progress. See Grosaman and Helpman (1991a, ch.12).

${ }^{37}$ This result relies on the assumption that there are no knowledge spillovers from North to South and that the equilibrium wage gap is such that Southern firms charge monopoly prices rather than limit prices. If either of these assumptions is reversed, an increase in $L_{N}$ boosts the long-run rate of innovation, $g$.
} 
when $L_{N}$ increases, while the relative wage of the South rises when $L_{S}$ increases. These results are the opposite of those derived by Krugman, who took the rates of innovation and technology transfer to be exogenous and implicitly assumed that product development and reverse engineering require no resources.

Several authors have studied whether the South benefits in welfare terms from protecting foreign intellectual property rights, and whether a failure to protect these rights would damage the North. Chin and Grossman (1990) developed a partialequilibrium, duopoly model in which a Northern firm engages in cost-reducing R\&D while recognizing that its Southern competitor might or might not be able to copy its improvements, depending on the property rights regime. In this setting, the North always suffers from a failure of the South to protect intellectual property rights, while the South typically gains from allowing copying. ${ }^{38}$ Deardorff (1992) established similar results for product innovation. In his partial-equilibrium setting, there are many potential new products that offer differing amounts of surplus and bear differing R\&D costs. Although more new products are introduced when property rights are protected, the South's gain from this typically is dwarfed by its loss of consumer surplus due to monopoly pricing. Interestingly, Deardorff shows that as patent protection is extended to a larger and larger portion of the world, the effect on aggregate world welfare of extending protection further eventually becomes negative.

A case where the South might wish to protect Northern intellectual property rights has been described by Diwan and Rodrik (1991). In their model, the North and South have different preferences over the direction that technological progress should take (e.g., the types of goods that should be invented). Then, patent protection in the South can induce Northern innovators to invent products more to the Southern consumers' liking, whereas a lack of such protection would lead to very undesirable products from the South's point of view.

The analysis in Helpman (1993) is closest in spirit to what we have described

\footnotetext{
${ }^{38}$ In this partial equilibrium setting, a lack of enforcement of intellectual property rights always reduces the incentives to innovate in the North. The South could be harmed by the reduction in technological progress, but only if its share in world consumption of the product is very large.
} 
here. He considers a general equilibrium in which new goods are invented and manufactured with labor in the North and old goods are manufactured with labor in the South. All consumers have CES preferences, so that Northern producers of goods whose technologies have not yet been mastered in the South practice mark-up pricing. Technology transfer to the South takes place at an exogenous rate $m=\dot{n}_{S} / n_{N}$ and requires no Southern resources. Helpman treats the rate of imitation as a policy parameter reflecting the strictness of the South's property rights regime, and he supposes that all Southern firms are able to produce any good whose technology diffuses there, so that old goods are sold competitively. In this setting, a tightening of the intellectual property rights regime as reflected in a fall in $m$ spurs Northern innovation upon impact, but slows the rate of innovation in the long run. If the world economy is in a steady state before $m$ falls, the equilibrium shift in the time profile of new product development harms the South, as does the reallocation of production from the low cost to the high cost producer and the adverse movement in the South's terms of trade. In short, the South must lose from an exogenous fall in $m$. As for the North, the change in the time profile of product availability and the reallocation of production from North to South contribute to a welfare loss, but there are offsetting effects due to an adjustment of the savings rate and a favorable movement in the terms of trade. Still, the North must lose from a decline in $m$ if the rate of imitation is initially low.

\subsection{Direct Foreign Investment and International Licensing}

We have considered that some types of knowledge may flow across international borders as an inevitable consequence of the public-good nature of information. We have also noted that some knowledge may flow from one country to another due to the intentional actions of would-be imitators. But we have not examined the incentives that innovators themselves have to transfer knowledge and technologies abroad.

Technology transfer by innovating firms can take one of two forms. An innovator can establish a wholly or partly-owned offshore subsidiary, and thereby maintain full control over the use of its proprietary technology. Or it can license the technology 
in an arms-length transaction with a foreign firm, and rely on the enforcement of contractual terms to limit the diffusion of its intellectual property. Much has been written about the incentives firms have to engage in one or both of these types of activities. It is beyond the scope of this chapter to review this literature thoroughly; instead we briefly comment on a few themes and then point to some issues that the literature has hardly addressed.

There are two obvious reasons why a firm might wish to take its technology abroad. First, production costs might be lower there. Second, the firm might be able to avoid some of the costs of serving the foreign market, such as transportation charges and tariff levies. Markusen (1984) and Helpman (1984b) have developed models of direct foreign investment based on the first of these considerations, while Horstmann and Markusen (1992) and Brainard (1993) provide modern treatments of the second. ${ }^{39}$ As Horstmann and Markusen show quite clearly, multinational firms are most likely to emerge when the fixed costs of adding a plant or maintaining a subsidiary are small, compared with the size of transport costs, trade barriers, and the fixed costs of operating a firm. It should be noted that technology plays an important role in these models of the multinational corporation in at least two respects. First, a theory of multinational investment must explain not only why a firm would wish to locate some of its activities offshore, but also why the firm would be able to compete with locally owned establishments in performing these activities despite the disadvantages that derive from unfamiliarity with local customs, language, business practices, etc. Proprietary access to a unique technology provides just such an explanation. Second, research and development is exactly the sort of firm-level fixed cost that generates economies of multi-plant production.

Licensing provides an alternative means to the same ends. By licensing its technology to a local firm, an innovator can reap the benefits of lower production costs, or gain access to a protected market, without suffering the penalties of operating in an unfamiliar business environment. ${ }^{40}$ But licensing has its own costs and risks. First,

\footnotetext{
${ }^{39}$ The recent literature on the role of multinational corporations in international trade is reviewed by Krugman in Chapter 1 of this Handbook.

${ }^{40}$ Feenstra and Judd (1982) have formulated a static model of monopolistic competition and
} 
since it is impossible to write a complete contract specifying every possible contingency that may arise, a patent holder may find itself unable to respond as flexibly to unforeseen events when it is locked into a contractual licensing arrangement as when it is operating its own manufacturing facility [see Ethier (1986)]. Second, an innovative firm may be unable to prevent all forms of opportunistic behavior by a licensee after its technology has been transferred; the licensee might, for example, use the technology in markets other than the one specified in the agreement or it might use the knowledge it gains from the agreement as a springboard for developing a different or better technology of its own. Finally, the innovative firm may be unable to credibly commit to forego opportunities of its own. If a potential licensee expects that the licensor will eventually enter the market itself either by opening a local subsidiary or with exports, its willingness to pay for the license will be diminished relative to the case where it expects to enjoy a monopoly. Part of the incidence of any anticipated dissipation of profits will fall on the innovator that is looking to rent out its technology [see Grossman and Helpman (1991a, ch.7)].

An additional risk associated with both direct foreign investment and licensing is that they might speed up the process of imitation and diffusion. It may be that learning spillovers are more prevalent when production takes place locally than when goods are imported from a foreign manufacturing base. Then the innovating firm must weigh the profit gains associated with having lower production costs against the potential losses from losing its monopoly position more rapidly. Ethier and Markusen (1991) study this aspect of a firm's decision problem.

Many papers in the literature on direct foreign investment and licensing focus on a firm's choice of how best to exploit its technological advantage once that advantage has already been developed. In contrast, there have been very few papers that have addressed the important question of how opportunities for direct investment and licensing affect the pace and pattern of technological progress. For this, the static trade in which the fixed cost of entry is interpreted to be an R\&D charge and firms can sell their technologies developed in one country to producers in the other in order to take advantage of lower production costs there. This model is analogous, in many ways, to Helpman's (1984b) model of direct foreign investment. 
models-which have served well for investigating firms' optimal decisions at a point in time-will not suffice.

Grossman and Helpman (199la, ch.7) have introduced direct foreign investment and international licensing into a dynamic model; namely, the two-country model of endogenous innovation with international knowledge spillovers that was described in Section 3.1. They have shown that (costless) foreign investment or (costless) international licensing of technologies can enlarge the set of divisions of the world factor endowment that give rise to factor price equalization. In their analysis, some firms that develop new technologies in the human-capital-rich country may find it profitable to manufacture their newly-invented products (either themselves, or by entering a licensing agreement) in the unskilled-labor-rich country. Then the longrun pattern of trade may involve the human-capital-rich country as a net importer of high-technology products, as subsidiaries of innovating firms export their finished products back home. This, of course, is similar to the predictions about the trade pattern in static models of multinational corporations; see, for example, Helpman and Krugman (1985, chs.12,13).

The incentives for exploiting technological advantage through foreign production are especially great in the context of North-South trade. In fact, Vernon's (1966) seminal discussion of product-cycle trade envisioned not the production of old goods by indigenous Southern producers, but rather the eventual shifting of production by innovative Northern firms to their subsidiaries in the South. Lai (1992) attempts to capture the original Vernon notion in a variant of Grossman and Helpman's (1991a, ch.11) model of the product cycle. He allows innovators to transfer their production activities to the South costlessly once the technology becomes "standardized". This happens randomly and exogenously, he assumes, some time after the new technology has been introduced. In a similar vein, Liu (1992) introduces the possibility of technology licensing into the same Grossman and Helpman model. Licensing too is treated as costless, except that the technology must be adopted for use in the South before production can begin there. Adoption involves a fixed cost per product that varies with the stock of knowledge in the South. 
These treatments of foreign subsidiaries and licensing pacts (including our own!) are too simple, however. They neglect the above mentioned risks associated with these types of activities, such as the risk of faster loss of monopoly power, the risk of opportunistic behavior on the part of licensees, and the risk that contingencies will arise that are not foreshadowed in the licensing agreement. The dynamic models must be extended to incorporate these and other realistic aspects of the different modes of technology transfer (some of which have been dealt with in the static literature), before a convincing answer can be given to the question of how such transfers affect the incentives for innovation.

Another topic deserving further attention is how policies affect the transfer of technology. Should governments in the North take actions to impede the transfer of technology as is often suggested in the public policy debates, or would this have adverse consequences for the rate at which new technologies are developed? And what can the South do to encourage technology transfer to indigenous agents without causing the Northern innovators to take their business elsewhere? To answer these questions we will need models that pay closer attention to how knowledge is transmitted within and between firms. 


\section{References}

[1] Aghion P. and P. Howitt, 1992, A model of growth through creative destruction, Econometrica, 60, 323-351.

[2] Arrow, K.J., 1962, Economic welfare and the allocation of resources for inventions, in: R.R. Nelson, ed., The rate and direction of inventive activity (Princeton University Press, Princeton) 609-626.

[3] Bardhan, P.K., 1970, Economic growth development and foreign trade (John Wiley and Sons, New York).

[4] Becker, G., 1952, A note on multi-country trade, American Economic Review, $42,558-568$.

[5] Bernstein, J.I. and P. Mohnen, 1994, International r\&d spillovers between U.S. and Japanese r\&d intensive sectors, National Bureau of Economic Research Working Paper No. 4682.

[6] Bhagwati, J.N., 1958a, International trade and economic expansion, American Economic Review, 48, 941-953.

[7] Bhagwati, J.N., 1958b, Immiserizing growth: A geometrical note, Review of Economic Studies, 25, 201-205.

[8] Bloomfield, A.I., 1978, The impact of growth and technology on trade in nineteenth-century British thought, History of Political Economy, 10, 608-635.

[9] Boldrin, M. and J.A. Sheinkman, 1988, Learning by doing, international trade and growth: A note, in: SFI Studies in the Sciences of Complexity (AddisonWesley, Reading MA).

[10] Brainard, S. L., 1993, A simple theory of multinational corporations and trade with a trade-off between proximity and concentration, National Bureau of Economic Research Working Paper No. 4269. 
[11] Bresiz, E.S., P.R. Krugman, and D. Tsiddon, 1993, Leapfrogging in international competition: A theory of cycles in national technological leadership, American Economic Review, 83, 1211-1219.

[12] Chin, J. and G.M. Grossman, 1990, International property rights and northsouth trade, in: R.W. Jones and A.O. Krueger, eds., The political economy of international trade (Basil Blackwell, Cambridge, MA) 90-107.

[13] Cicconi, A., and K. Matsuyama, 1993, Start-up costs and pecuniary externalities as barriers to economic development, Institute for Empirical Macroeconomics Discussion Paper No. 83, Federal Reserve Bank of Minneapolis.

[14] Coe, D.T. and E. Helpman, 1994, International r\&d spillovers, National Bureau of Economic Research Working Paper No. 4444.

[15] Davis, D.R., 1994, Intra-industry trade: A Heckscher-Ohlin-Ricardo approach, mimeo, Harvard University.

[16] Deardorff, A.V., 1992, Welfare effects of global patent protection, Economica, $59,35-51$.

[17] Dinopoulos, E., J.F. Oehmke and P.S. Segerstrom, 1993, High-technologyindustry trade and investment: The role of factor endowments, Journal of International Economics, 34, 49-71.

[18] Diwan, I. and D. Rodrik, 1991, Patents, appropriate technology, and north-south trade, Journal of International Economics, 30, 27-47.

[19] Dixit, A.K. and J.E. Stiglitz, 1993, Monopolistic competition and optimum product diversity: Reply, American Economic Review, 83, 302-304.

[20] Dornbush, R., S. Fischer and P.A. Samuelson, 1977, Comparative advantage, trade and payments in a Ricardian model with a continuum of goods, American Economic Review, 67, 823-839. 
[21] Eaton, J. and S. Kortum, 1994, International patenting and technology diffusion, mimeo, Boston University.

[22] Ethier,W.J., 1982a, National and international returns to scale in the modern theory of international trade, American Economic Review, 72, 389-405.

[23] Ethier, W.J., 1982b, Decreasing cost in international trade and Frank Graham's argument for protection, Econometrica, 50, 1243-1268.

[24] Ethier, W.J., 1986, The multinational firm, Quarterly Journal of Economics, 80, 805-833.

[25] Ethier, W.J. and J.R. Markusen, 1991, Multinational firms, technology diffusion and trade, National Bureau of Economic Research Working Paper No.3825.

[26] Feenstra, R., 1990, Trade and uneven growth, National Bureau of Economic Research Working Paper No. 3276.

[27] Feenstra, R., and K. Judd, 1982, Tariffs, technology transfer and welfare, Journal of Political Economy, 90, 1142-1165.

[28] Findlay, R., 1984, Growth and development in trade models, in: R.W. Jones and P.B. Kenen, eds., Handbook of international economics, vol.1 (North-Holland, Amsterdam) 185-236.

[29] Findlay, R. and H. Grubert, 1959, Factor intensities, technological progress and the terms of trade, Oxford Economic Papers, 11 111-121.

[30] Grossman, G.M., and E. Helpman, 1990a, Comparative advantage and long-run growth, American Economic Review, 80, 796-815.

[31] Grossman, G.M., and E. Helpman, 1990b, Trade, innovation and growth, American Economic Review, 80 (Papers and Proceedings) 86-91.

[32] Grossman, G.M. and E. Helpman, 1991a, Innovation and growth in the global economy (The MIT Press, Cambridge, MA). 
[33] Grossman, G.M., and E. Helpman, 1991b, Quality ladders in the theory of growth, Review of Economic Studies, 58, 43-61.

[34] Grossman, G.M., and E. Helpman, 1991c, Trade, knowledge spillovers and growth, European Economic Review, 35, 517-526.

[35] Helpman, E., 1984a, Increasing returns, imperfect markets, and trade theory, in: R.W. Jones and P.B. Kenen, eds., Handbook of international economics, vol.1 (North-Holland, Amsterdam) 325-365.

[36] Helpman, E., 1984b, A simple theory of trade with multinational corporations, Journal of Political Economy, 92, 451-472.

[37] Helpman, E., 1993, Innovation, imitation and intellectual property rights, Econometrica, 61, 1247-1280.

[38] Helpman, E. and P.R. Krugman, 1985, Market structure and foreign trade (The MIT Press, Cambridge, MA).

[39] Hicks, J.R., 1953, An inaugural lecture, Oxford Economic Papers, 5, 117-135.

[40] Horstmann, I.J. and J.R. Markusen, 1992, Endogenous market structures in international trade, Journal of International Economics, 32, 109-129.

[41] Irwin, D.A. and P.J. Klenow, 1994, Learning-by-doing spillovers in the semiconductor industry, Journal of Political Economy, 102, forthcoming.

[42] Jaffe, A., M. Trajtenberg and R. Henderson, 1993, Geographic localization of knowledge spillovers as evidenced by patent citations, Quarterly Journal of Economics, 108, 577-598.

[43] Jones, R.W., 1961, Comparative advantage and the theory of tariff: A multicountry, multi-commodity model, Review of Economic Studies, 28, 161-175.

[44] Jones, R.W., 1965, The structure of simple general equilibrium models, Journal of Political Economy, 73, 557-572. 
[45] Jones, R.W., 1970, The role of technology in the theory of international trade, in: R.Vernon, ed., The technology factor in international trade (National Bureau of Economic Research, New York) 73-92.

[46] Judd, K.L., 1985, On the performance of patents, Econometrica, 53, 567-586.

[47] Krugman, P.R., 1979, A model of innovation, technology transfer, and the world distribution of income, Journal of Political Economy, 87, 253-266.

[48] Krugman, P.R., 1986, A 'technology gap' model of international trade, in: K. Jungenfelt and D. Hague, eds., Structural adjustment in developed open economics (Macmillan Press, London) 35-49.

[49] Krugman, P.R., 1987, The narrow moving band, the dutch disease, and the competitive consequences of Mrs. Thatcher: Notes on trade in the presence of dynamic scale economics, Journal of Development Economics, 27, 41-55.

[50] Krugman, P.R., 1991, History vs. expectations, Quarterly Journal of Economics, 106, 651-667.

[51] Lai, E., 1992, International intellectual property rights protection and the rate of product innovation, mimeo, Vanderbilt University.

[52] Lichtenberg, F., 1992, R\&D investments and international productivity differences, in: H. Siebert, ed., Economic growth in the world economy: Symposium 1992 (Tubingen, J.C.B. Mohr).

[53] Lucas, R.E. Jr., 1988, On the mechanics of economic development, Journal of Monetary Economics, 22, 3-42.

[54] Markusen, J.R., 1984, Multinationals, multi-plant economies, and the gains from trade, Journal of International Economics, 14, 205-226.

[55] Markusen, J.R., 1991, First mover advantages, blockaded entry, and the economics of uneven development, in: E. Helpman and A. Razin, eds., International trade and trade policy (The MIT Press, Cambridge, MA) 245-269. 
[56] Markusen, J.R., and L.E.O. Svenson, 1985, Trade in goods and factors with international differences in technology, International Economic Review, 26, 175 192.

[57] Matsuyama, K., 1992, Agricultural productivity, comparative advantage and economic growth, Journal of Economic Theory, 58, 317-334.

[58] Murphy, K.M., A.Shleifer and R.W. Vishny, 1989, Industrialization and the big push, Journal of Political Economy, 97, 1003-1026.

[59] Ofer, G., 1991, International effects of trade policy" MA dissertation, Tel-Aviv University (Hebrew).

[60] Posner, M.V., 1961, International trade and technological progress, Oxford Economic Papers, 13, 323-341.

[61] Ricardo, D., 1951-1955, in: P. Sraffa, ed., The works and correspondence of David Ricardo (Cambridge).

[62] Rivera-Batiz, L.A. and P.M. Romer, 1991, International trade with endogenous technological change, European Economic Review, 35, 715-721.

[63] Rodriguez, A., 1993, The division of labor and economic development, mimeo, Stanford University.

[64] Rodrik, D., 1993, Do low-income countries have a high-wage option? National Bureau of Economic Research Working Paper No. 4451.

[65] Segerstorm, P.S., T.C.A. Anant and E. Dinopoulos, 1990, A Schumpeterian model of product life cycle, American Economic Review, 80, 1077-1091.

[66] Stokey, N., 1991, Human capital, product quality, and growth, Quarterly Journal of Economics, $425,587-616$.

[67] Taylor, M.S., 1993, Quality ladders and Ricardian trade, Journal of International Economics, 34, 225-243. 
[68] Vernon, R., 1966, International investment and international trade in the product cycle, Quarterly Journal of Economics, 80, 190-207.

[69] Wilson, C.A., 1980, On the general structure of Ricardian models with continuum of goods: Application to growth, tariff theory, and technical change, Econometrica, 48, 1675-1702.

[70] Yanagawa, N., 1993, Economic development in a world with many countries, mimeo, Keio University.

[71] Young, A., 1991, Learning by doing and the dynamic effects of international trade, Quarterly Journal of Economics, 105, 369-405. 
Figure 1

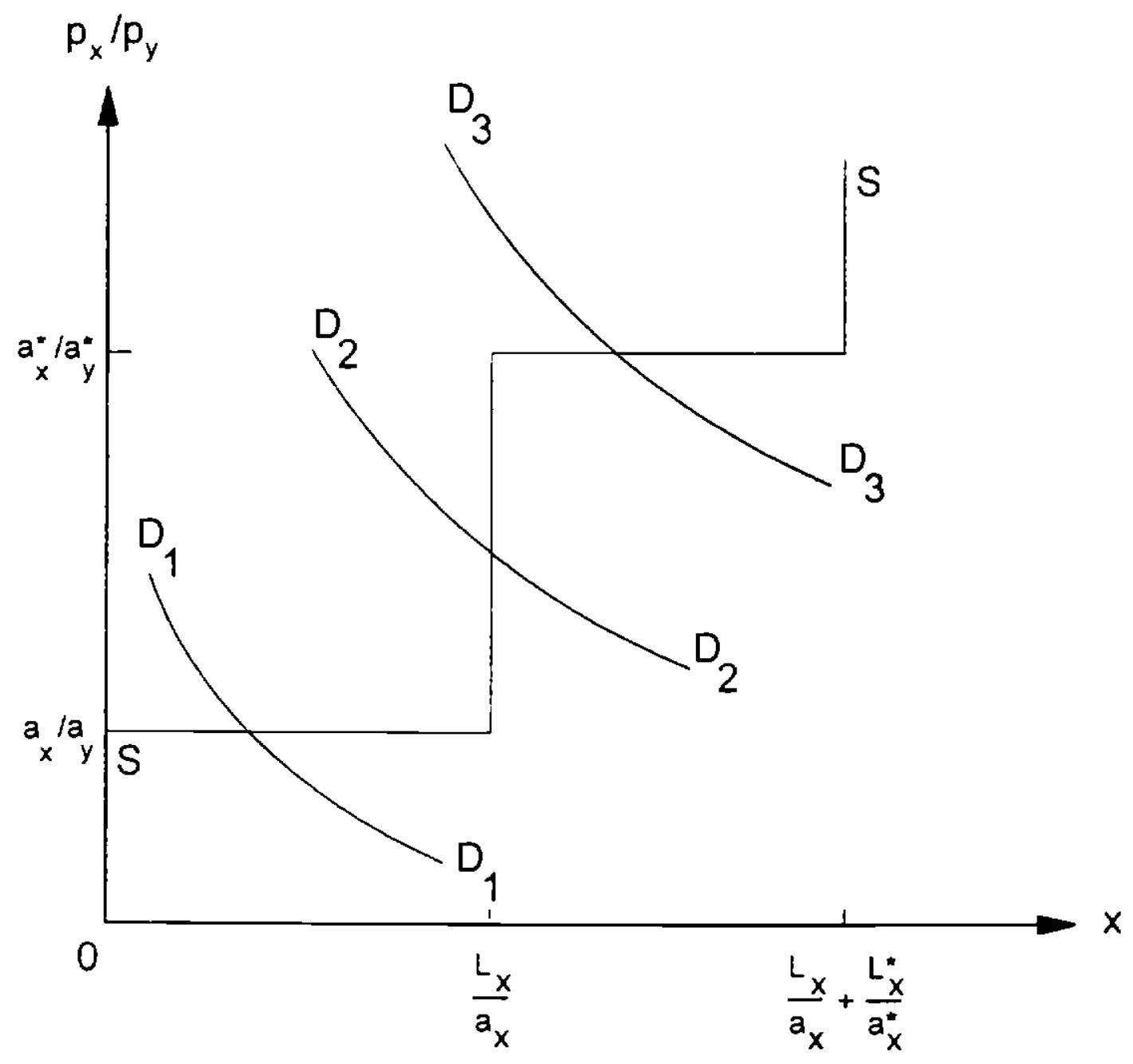


Figure 2

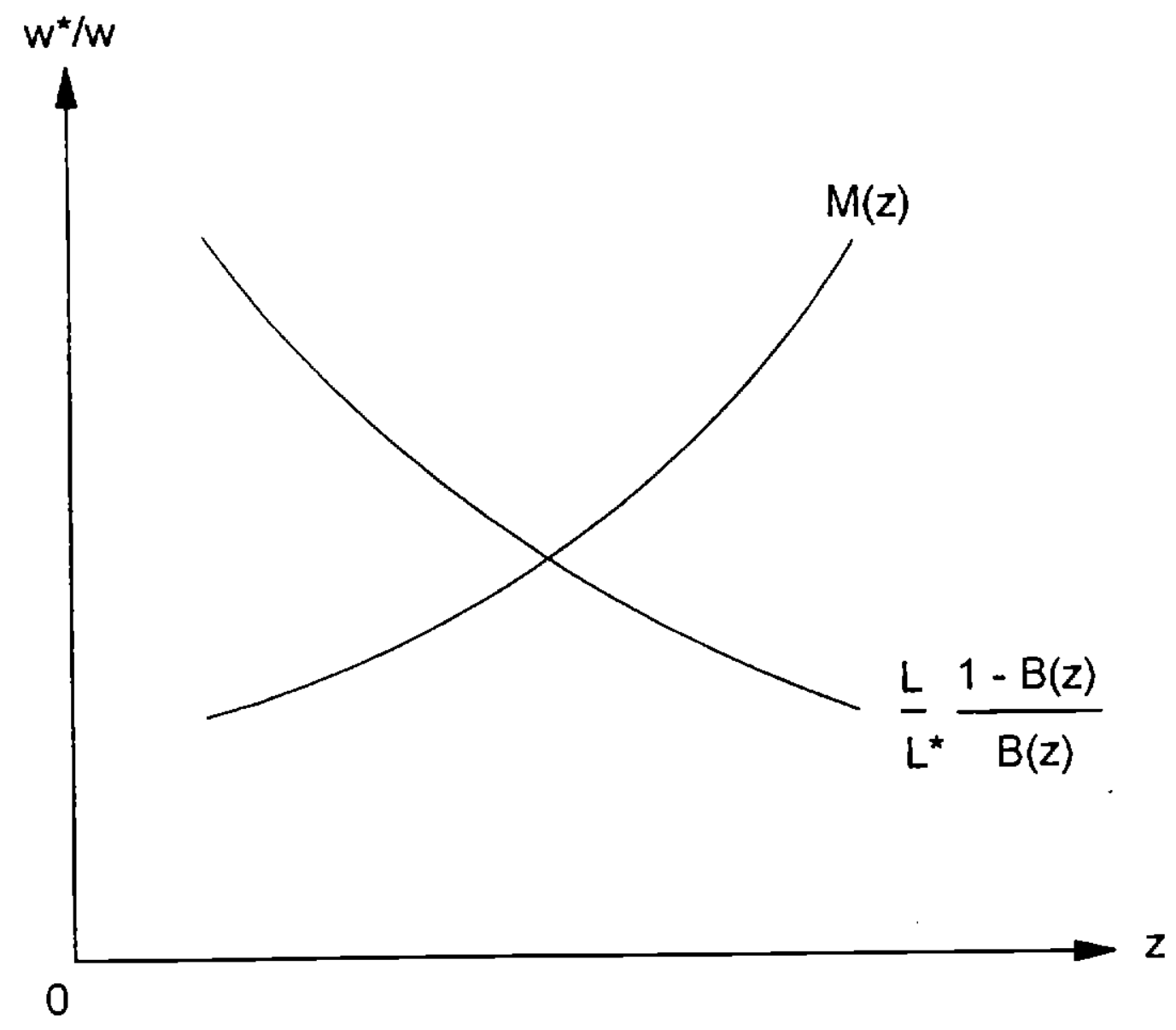


Figure 3

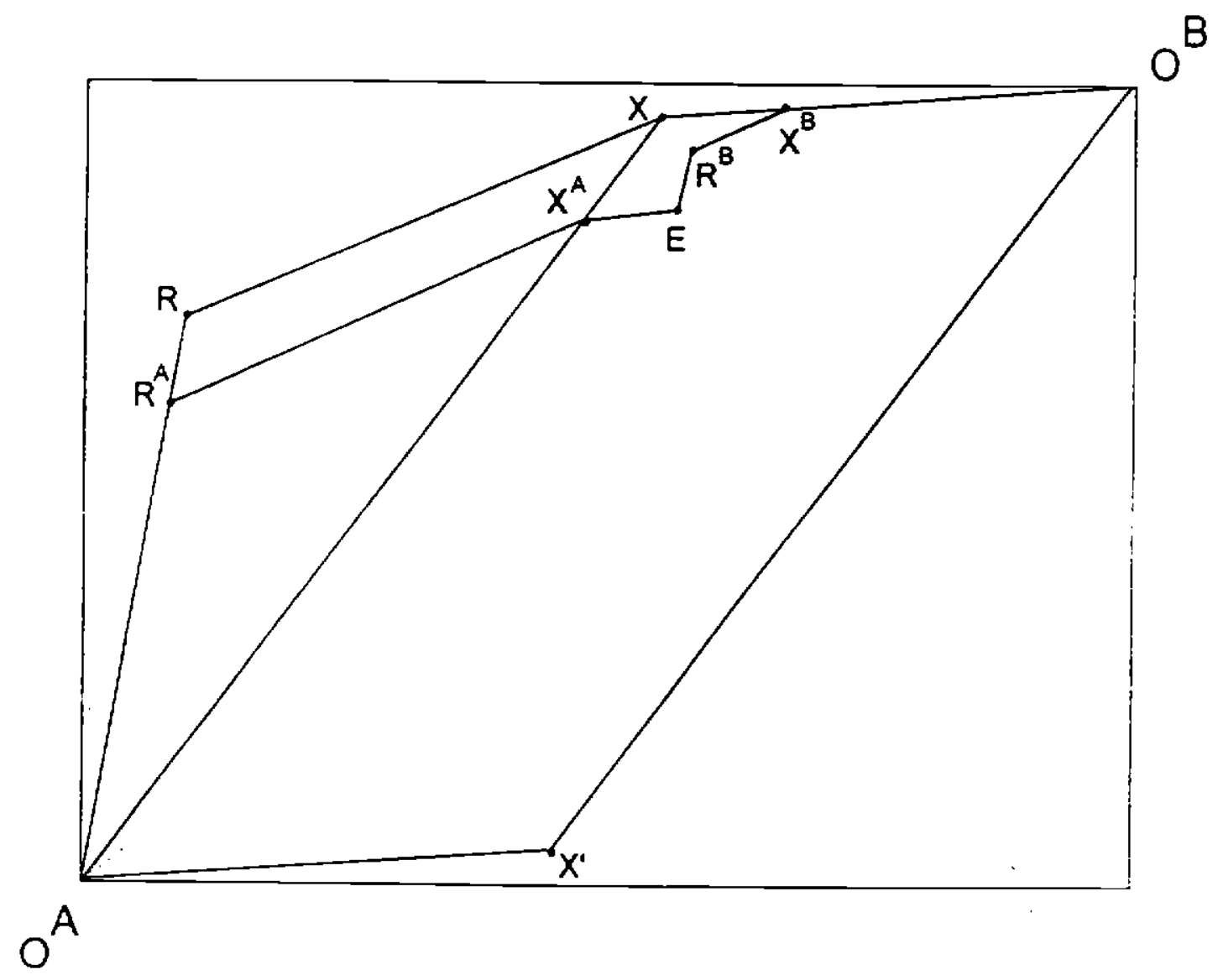


Figure 4

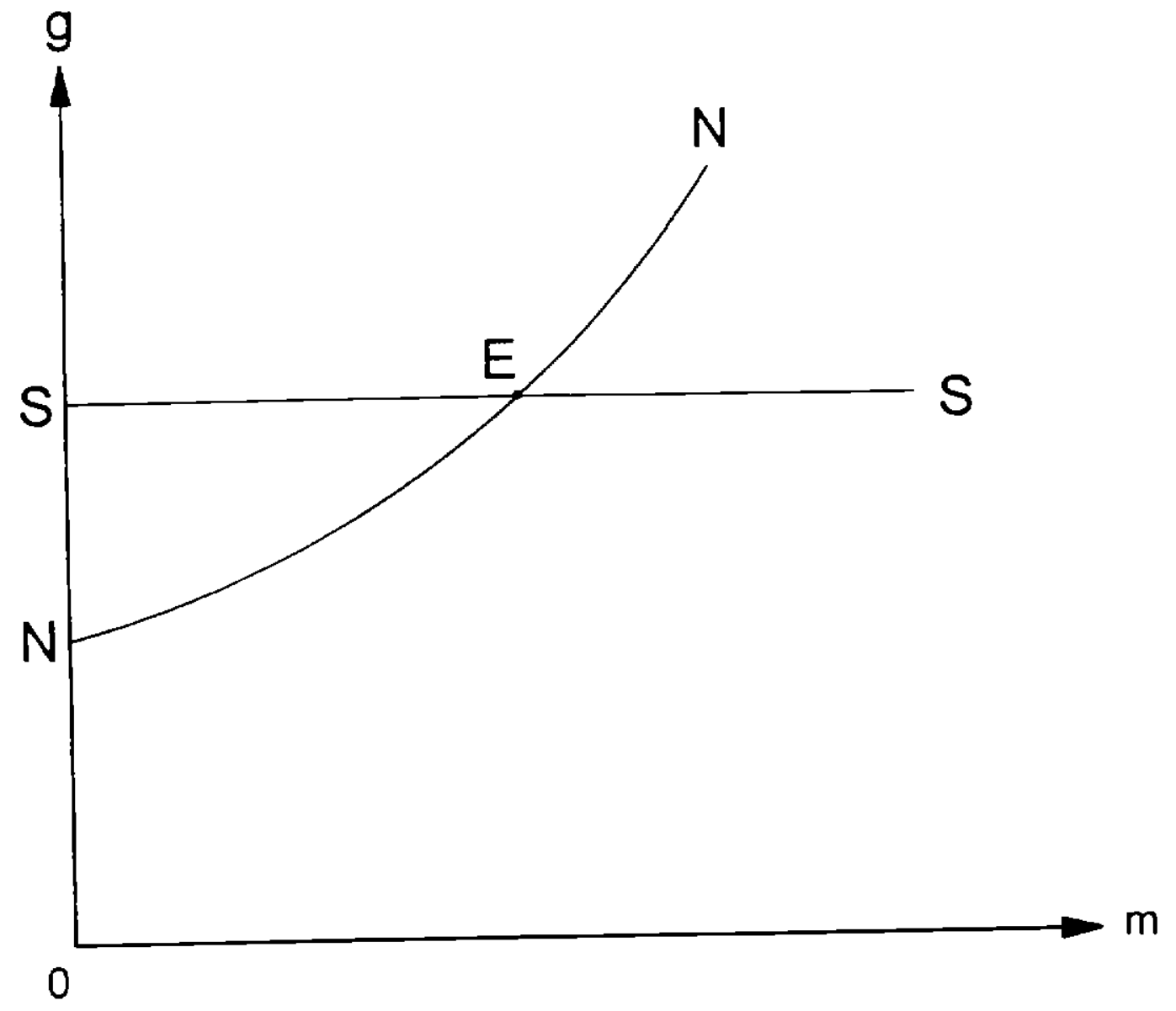


To order any of these papers, see instructions at the end of the list. To subscribe to all NBER Working Papers or the papers in a single area, see instructions inside the back cover. A complete list of NBER Working Papers and Reprints can be accessed on the Internet by using our gopber at aber.harvard.edu.

\begin{tabular}{|c|c|c|c|}
\hline Number & Author(s) & Title & Date \\
\hline 4869 & $\begin{array}{l}\text { Harry Grubert } \\
\text { Joel Slemrod }\end{array}$ & $\begin{array}{l}\text { The Effect of Taxes on Investment and } \\
\text { Income Shifting to Puerto Rico }\end{array}$ & $9 / 94$ \\
\hline 4870 & Dani Rodrik & $\begin{array}{l}\text { What Does the Political Economy Literature } \\
\text { on Trade Policy (Not) Tell Us That We } \\
\text { Ought to Know? }\end{array}$ & $9 / 94$ \\
\hline 4871 & Lars E. O. Svensson & $\begin{array}{l}\text { Estimating and Interpreting Forward } \\
\text { Interest Rates: Sweden 1992-1994 }\end{array}$ & $9 / 94$ \\
\hline 4872 & George J. Borjas & Immigration and Welfare, 1970-1990 & $9 / 94$ \\
\hline 4873 & $\begin{array}{l}\text { José De Gregorio } \\
\text { Federico Sturzenegger }\end{array}$ & $\begin{array}{l}\text { Credit Markets and the Welfare Costs } \\
\text { of Inflation }\end{array}$ & $10 / 94$ \\
\hline 4874 & $\begin{array}{l}\text { Brandice J. Canes } \\
\text { Harvey S. Rosen }\end{array}$ & $\begin{array}{l}\text { Following in Her Footsteps? Women's Choices } \\
\text { of College Majors and Faculty Gender Composition }\end{array}$ & $10 / 94$ \\
\hline 4875 & $\begin{array}{l}\text { Raghuram G. Rajan } \\
\text { Luigi Zingales }\end{array}$ & $\begin{array}{l}\text { What Do We Know about Capital Structure? } \\
\text { Some Evidence from Intemational Data }\end{array}$ & $10 / 94$ \\
\hline 4876 & $\begin{array}{l}\text { Gene Grossman } \\
\text { Ehanan Helpman }\end{array}$ & Foreign Investment with Endogenous Protection & $10 / 94$ \\
\hline 4877 & $\begin{array}{l}\text { Gene Grossman } \\
\text { Elhanan Helpman }\end{array}$ & $\begin{array}{l}\text { Electoral Competition and Special Interest } \\
\text { Politics }\end{array}$ & $10 / 94$ \\
\hline 4878 & $\begin{array}{l}\text { C. Keith Head } \\
\text { John C. Ries } \\
\text { Deborah L. Swenson }\end{array}$ & $\begin{array}{l}\text { The Altraction of Foreign Manufacturing } \\
\text { Investments: Investment Promotion and } \\
\text { Agglomeration Economies }\end{array}$ & $10 / 94$ \\
\hline 4879 & David M. Cutler & Market Failure in Small Group Health Insurance & $10 / 94$ \\
\hline 4880 & $\begin{array}{l}\text { Douglas Holtz-Eakin } \\
\text { John R. Penrod } \\
\text { Harvey S. Rosen }\end{array}$ & $\begin{array}{l}\text { Health Insurance and the Supply of } \\
\text { Entrepreneurs }\end{array}$ & $10 / 94$ \\
\hline 4881 & $\begin{array}{l}\text { Nouriel Roubini } \\
\text { Gian Maria Milesi-Ferretti }\end{array}$ & $\begin{array}{l}\text { Taxation and Endogenous Growth in Open } \\
\text { Economies }\end{array}$ & $10 / 94$ \\
\hline 4882 & $\begin{array}{l}\text { Nouriel Roubini } \\
\text { Gian Maria Milesi-Ferretti }\end{array}$ & $\begin{array}{l}\text { Optimal Taxation of Human and Physical Capital } \\
\text { in Endogenous Growth Models }\end{array}$ & $10 / 94$ \\
\hline 4883 & $\begin{array}{l}\text { Raquel Femandez } \\
\text { Richard Rogerson }\end{array}$ & $\begin{array}{l}\text { Public Education and Income Distribulion: A } \\
\text { Quantitative Evaluation of Education Finance Reforn }\end{array}$ & $\begin{array}{l}10 / 2 \\
\mathrm{~m}\end{array}$ \\
\hline
\end{tabular}


To order any of these papers, see instructions at the end of the list. To subscribe to all NBER Working Papers or the papers in a single area, see instructions inside the back cover, A complete list of NBER Working Papers and Reprints can be accessed on the Internet by using our gopher at nber.harvard.edu.

\begin{tabular}{|c|c|c|c|}
\hline Number & Author(s) & $\underline{\text { Tille }}$ & Date \\
\hline 4884 & $\begin{array}{l}\text { R. Glenn Hubbard } \\
\text { Jonathan Skinner } \\
\text { Stephen P. Zeldes }\end{array}$ & Precautionary Saving and Social Insurance & $10 / 94$ \\
\hline 4885 & Martin Feldstein & Fiscal Policies. Capital Formalion and Capitalism & $10 / 94$ \\
\hline 4886 & $\begin{array}{l}\text { Oliver Hart } \\
\text { John Moore }\end{array}$ & $\begin{array}{l}\text { Debt and Seniority: An Analysis of the Role } \\
\text { of Hand Claims in Constraining Management }\end{array}$ & $10 / 94$ \\
\hline 4887 & $\begin{array}{l}\text { Ricardo J. Caballero } \\
\text { Eduardo M.R.A. Engel }\end{array}$ & $\begin{array}{l}\text { Explaining Investment Dynamics in U.S. } \\
\text { Manufacturing: A Generalized }(S, s) \text { Approach }\end{array}$ & $10 / 94$ \\
\hline 4888 & $\begin{array}{l}\text { Martin Feldstein } \\
\text { James H. Stock }\end{array}$ & $\begin{array}{l}\text { Measuring Money Growth When Financial } \\
\text { Markets Are Changing }\end{array}$ & $10 / 94$ \\
\hline 4889 & $\begin{array}{l}\text { Mark Hooker } \\
\text { Michael Knetter }\end{array}$ & $\begin{array}{l}\text { Unemployment Effects of Military Spending: } \\
\text { Evidence from a Panel of Stales }\end{array}$ & $10 / 94$ \\
\hline 4890 & $\begin{array}{l}\text { John R. Graham } \\
\text { Campbell R. Harvey }\end{array}$ & $\begin{array}{l}\text { Market Timing Ability and Volatility } \\
\text { Implied in Investment Newsletters' } \\
\text { Asset Allocalion Recommendations }\end{array}$ & $10 / 94$ \\
\hline 4891 & W. Kip Viscusi & $\begin{array}{l}\text { Cigarette Taxation and the Social } \\
\text { Consequences of Smoking }\end{array}$ & $10 / 94$ \\
\hline 4892 & Alan M. Taylor & $\begin{array}{l}\text { Domestic Saving and International } \\
\text { Capital Flows Reconsidered }\end{array}$ & $10 / 94$ \\
\hline 4893 & $\begin{array}{l}\text { Maurice Obstfeld } \\
\text { Kenneth Rogoff }\end{array}$ & $\begin{array}{l}\text { The Intertemporal Approach to the } \\
\text { Current Account }\end{array}$ & $10 / 94$ \\
\hline 4894 & Michael M. Knetter & $\begin{array}{l}\text { Why Are Retail Prices in Japan So High?: } \\
\text { Evidence from German Export Prices }\end{array}$ & $10 / 94$ \\
\hline 4895 & Peter Diamond & Insulation of Pensions from Political Risk & $10 / 94$ \\
\hline 4896 & Lawrence H. Goulder & $\begin{array}{l}\text { Environmental Taxation and the "Double } \\
\text { Dividend": A Reader's Guide }\end{array}$ & 10,94 \\
\hline 4897 & $\begin{array}{l}\text { A. Lans Bovenberg } \\
\text { Lawrence H. Goulder }\end{array}$ & $\begin{array}{l}\text { Optimal Environmental Taxation in the Presence } \\
\text { of Other Taxes: General Equilibrium Analyses }\end{array}$ & $10 / 94$ \\
\hline 4898 & $\begin{array}{l}\text { Bany Eichengreen } \\
\text { Andrew K. Rose } \\
\text { Charles Wyplosz }\end{array}$ & $\begin{array}{l}\text { Speculative Attacks on Pegged Exchange Rates: } \\
\text { An Empirical Exploration with Special Reference } \\
\text { to the European Monetary System }\end{array}$ & $10 / 94$ \\
\hline
\end{tabular}


To order any of these papers, see instructions at the end of the list. To subscribe to all NBER Working Papers or the papers in a single area, see instructions inside the back cover. A complete list of NBER Working Papers and Reprints can be accessed on the Internet by using our gopher at nber.haryard.edu.

\begin{tabular}{|c|c|c|c|}
\hline Number & Author(s) & Title & $\underline{\text { Date }}$ \\
\hline 4899 & Shane Greenstein & $\begin{array}{l}\text { From Superminis to Supercomputers: Estimating } \\
\text { Surplus in the Computing Market }\end{array}$ & $10 / 94$ \\
\hline 4900 & $\begin{array}{l}\text { Orazio P. Attanasio } \\
\text { Thomas C. DeLeire }\end{array}$ & $\begin{array}{l}\text { IRAs and Household Saving Revisited: } \\
\text { Some New Evidence }\end{array}$ & $10 / 94$ \\
\hline 4901 & $\begin{array}{l}\text { Timothy F. Bresnahan } \\
\text { Shane Grecnstein }\end{array}$ & $\begin{array}{l}\text { The Competitive Crash in Large-Scale } \\
\text { Commercial Computing }\end{array}$ & $10 / 94$ \\
\hline 4902 & Joel Slemrod & Free Trade Taxation and Prolectionist Taxation & $10 / 94$ \\
\hline 4903 & $\begin{array}{l}\text { Assaf Razin } \\
\text { Efraim Sadka }\end{array}$ & $\begin{array}{l}\text { Resisting Migration: The Problems of Wage } \\
\text { Rigidity and the Social Burden }\end{array}$ & $10 / 94$ \\
\hline 4904 & $\begin{array}{l}\text { Emst R. Bendt } \\
\text { Linda Bui } \\
\text { David Reiley } \\
\text { Glen Urban }\end{array}$ & $\begin{array}{l}\text { The Roles of Marketing, Product Quality and } \\
\text { Price Competition in the Growth and } \\
\text { Composition of the U.S. Anti-Ulcer } \\
\text { Drug Industry }\end{array}$ & $10 / 94$ \\
\hline 4905 & $\begin{array}{l}\text { Thomas C. Kinnaman } \\
\text { Don Fullerion }\end{array}$ & $\begin{array}{l}\text { How a Fee Per-Unit Garbage Affects } \\
\text { Aggregate Recycling in a Model with } \\
\text { Heterogeneous Households }\end{array}$ & 10,94 \\
\hline 4906 & Danicl S. Hamermesh & $\begin{array}{l}\text { Aging and Productivity, Rationality and } \\
\text { Malching: Evidence from Economists }\end{array}$ & $10 / 94$ \\
\hline 4907 & $\begin{array}{l}\text { Kooyul Jung } \\
\text { Yong-Cheol Kim } \\
\text { René M. Stulz }\end{array}$ & $\begin{array}{l}\text { Investment Opportunities, Managerial } \\
\text { Discretion, and the Security Issue } \\
\text { Decision }\end{array}$ & $10 / 94$ \\
\hline 4908 & $\begin{array}{l}\text { Jun-Koo Kang } \\
\text { René M. Stulz }\end{array}$ & $\begin{array}{l}\text { How Different is Japanese Corporate } \\
\text { Finance? An Investigation of the } \\
\text { Information Content of New Security Issues }\end{array}$ & $10 / 94$ \\
\hline 4909 & Robert J. Barro & Democracy and Growth & $10 / 94$ \\
\hline 4910 & Richard B. Freeman & Crime and the Job Market & $10 / 94$ \\
\hline 4911 & Rebecca M. Blank & The Dynamics of Part-Time Work & $11 / 94$ \\
\hline 4912 & George J. Borjas & $\begin{array}{l}\text { Ethnicity, Neighborhoods, and Human Capital } \\
\text { Extemalities }\end{array}$ & $11 / 94$ \\
\hline 4913 & $\begin{array}{l}\text { George J. Borjas } \\
\text { Bemt Bratsberg }\end{array}$ & $\begin{array}{l}\text { Who Leaves? The Outmigration of the } \\
\text { Foreign-Bom }\end{array}$ & $11 / 94$ \\
\hline 4914 & Christopher J. Ruhm & Economic Conditions and Alcohol Problems & 118 \\
\hline
\end{tabular}


To order any of these papers, see instructions at the end of the list. To subscribe to all NBER Working Papers or the papers in a single area, see instructions inside the back cover. A complete list of NBER Working Papers and Reprints can be accessed on the Internet by using our gopher at aber.harvardedu.

Number

Author(s)

Aaron S. Edlin

James M. Poterba

4917

4918

4919

4920

4921

4922

4923

4924

John M. Abowd

Francis Kramarz

David N. Margolis

Edward P. Lazear

Fumio Hayashi

Akihiko Matsui

Andrea Ichino

Kenneth A. Froot
Title

Date

Cadillac Contracts and Up-Front Payments: Efficient Investment Under Expectation Damages

Government Intervention in the Markels for Education and Health Care: How and Why?

High Wage Workers and High Wage Firms

Richard B. Freeman

Laurence C. Baker

Mitchell A. Petersen

Raghuram G. Rajan

Christopher L. Erickson

Richard C. Marston

James R. Hines, Jr.

Christopher J. Ruhm

Gene M. Grossman

Elharan Helpman
An Economic Analysis of Works Councils

$11 / 94$

A Model of Fiat Money and Barter

$11 / 94$

Does Competition From HMOs Affect

Fee-For-Service Physicians?

The Effect of Credit Market Competition on Lending Relationships

Wage Differentials in Italy: Market Forces, Institutions, and Inflation

Tests of Three Parity Conditions: Distinguishing

$11 / 94$ Risk Premia and Systematic Forecast Errors

Interest Allocation Rules, Financing Patterns,

$11 / 94$ and the Operations of U.S. Multinationals

Do Pensions increase the Labor Supply of

$11 / 94$

Older Men?

Technology and Trade

$11 / 94$

Copies of the above working papers can be obtained by sending $\$ 5.00$ per copy (plus $\$ 10.00$ per order for postage and handling for all locations outside the continental U.S.) to Working Papers, NBER, 1050 Massachusetts Avenue, Cambridge, MA 02138-5398. Advance payment is required on all orders. Payment may be made by check or credit card. Checks should be made payable to the NBER and must be in dollars drawn on a U.S. bank. If paying by credit card, include the cardholder's name, account number and expiration date. For all mail orders, please be sure to include your return address and telephone number. Working papers may also be ordered by telephone (617-868-3900), or by fax (617-868-2742). 


\section{National Bureau of Economic Research}

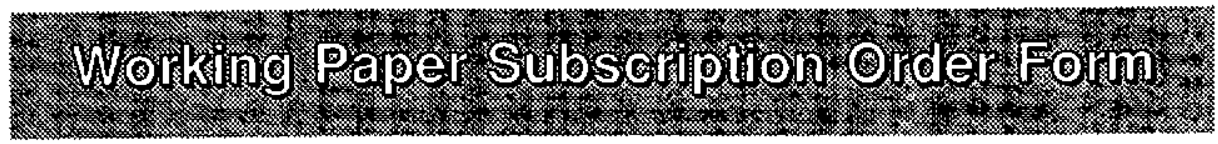

口 Full subscriptions*

Partlal subscriptions

$\square$ Corporate Finance

Stocks, Bonds, and Foreign Currency

口 International Finance and Macroeconomics

$\square$ International Trade and investment

口 Monetary Economics

C Economic Fluctuations

- Long-Run Economic Growth

S Sources of Productivity Growth

口 Taxation

- Labor Studies

$\square$ Economics of Health and Health Care

D Economics of the Elderly

$\square$ incustrial Organization

\begin{tabular}{lc}
\multicolumn{2}{c}{ Domestic } \\
\multicolumn{2}{c}{ Academic Libraries' } \\
Standard & Faculty Members \\
$\$ 1300$ & $\$ 650$
\end{tabular}

\begin{tabular}{lc}
\multicolumn{2}{c}{ Foreign } \\
& Academic Librariest \\
Standard & Faculty Members \\
$\$ 1625$ & $\$ 975$
\end{tabular}

0 Tochnical Working P

$\begin{array}{rr}300 & 75 \\ 300 & 75 \\ 270 & 135 \\ 270 & 135 \\ 150 & 75 \\ 270 & 135 \\ 150 & 75 \\ 70 & 35 \\ 270 & 135 \\ 270 & 135 \\ 150 & 75 \\ 70 & 35 \\ 70 & 35 \\ 70 & 35 \\ 70 & 35\end{array}$

$\begin{array}{rr}350 & 110 \\ 350 & 110 \\ 350 & 210 \\ 350 & 210 \\ 200 & 110 \\ 350 & 210 \\ 200 & 110 \\ 85 & 50 \\ 350 & 210 \\ 350 & 210 \\ 200 & 110 \\ 85 & 50 \\ 85 & 50 \\ 85 & 50 \\ 85 & 50\end{array}$

- Historical Development of the American Economy 70

- A full subscription includes all topics listed under "partiat subscriptions" except for Technicat Working Papers and papers on the Historical Deveiopment of the American Economy. These must be ordered in addition to the full subscription.

- Please inquire about subscription prices for Africa and Australia.

\section{PAYMENT OPTIONS}

$\square$ YES! Please begin my subscription to the NBER Working Paper Series. I have indicated above which papers I would like so recelve.

\section{By Phone: (617) 868-3900 \\ By FAX: (617) 868-2742 \\ By Mail: Publications Department \\ National Bureau of Economic Research \\ 1050 Massachusetts Ave}

$\square$ Payment in the amount of enclosed.

$\square$ Please charge my: $\square$ VISA $\square$ MasterCard

Card Number:

Card expiration:

Signature:
Please mail my papers to this address:

Name

Address

Phone:

FAX: 